\title{
La evolución cronológica del Castro de Viladonga (Castro de Rei, Lugo) a través del estudio de su cerámica común romana
}

\begin{abstract}
The chronological evolution of the hill-fort of Viladonga (Castro de Rei, Lugo) through the study of its Roman common pottery
\end{abstract}

SARA BARBAZÁN DOMÍNGUEZ

Museo de Prehistoria e Arqueoloxía de Vilalba, Rúa Dr. Domingo Goas 2, 27880, Vilalba, Lugo

Email: sarabzn@gmail.com

ORCID: https://orcid.org/0000-0002-1638-4745

\section{EDUARDO RAMIL REGO}

Museo de Prehistoria e Arqueoloxía de Vilalba, Rúa Dr. Domingo Goas 2, 27880, Vilalba, Lugo

Email: director@museovilalba.org

ORCID: http://orcid.org/0000-0003-1259-0899

\section{HugO LOZANO HERMIDA}

Departamento de Historia, Facultad de Geografía e Historia, Universidad de Santiago de Compostela, Praza da Universidade 1, 15782 Santiago de Compostela / Museo de Prehistoria e Arqueoloxía de Vilalba, Rúa Dr. Domingo Goas, 2, 27880 Vilalba, Lugo Email: hugo.lozano.hermida@usc.es

ORCID: https://orcid.org/0000-0002-0999-166X

Recibido: 12/03/2019. Aceptado: 07/05/2019.

Cómo citar: Barbazán, Sara, Ramil, Eduardo y Lozano, Hugo (2018): "La evolución cronológica del Castro de Viladonga (Castro de Rei, Lugo) a través del estudio de su cerámica común romana”. BSAA arqueología, LXXXIV, pp. 168-214.

DOI: https://doi.org/10.24197/ba.LXXXIV.2018.168-214

Resumen: Presentamos los resultados del estudio de la cerámica común romana procedente de cinco zonas del castro de Viladonga. Este castro, con una cronología que lo sitúa entre el s. Il y el $\checkmark$ d.C., ha proporcionado restos arqueológicos que han sido tradicionalmente encuadrados desde un momento prerromano hasta los tiempos de la germanización de la Gallaecia. Trataremos de determinar la evolución cronológica de su ocupación y caracterizar tipológicamente sus producciones cerámicas. 
Palabras clave: Galicia, Imperio Romano, Noroeste de la Península Ibérica, Castro, Cerámica común romana.

Abstract: We present the results of the study of Roman common pottery from five areas of the Viladonga hill-fort. This hill-fort, with a chronology that places it between the second century and the fifth century A.D., has provided archaeological remains that have been traditionally framed from a pre-Roman time until the times of the Germanization of Gallaecia. We will try to determinate the chronological evolution of their occupation and typologically characterize their pottery productions.

Keywords: Galicia, Roman Empire, Norwest of the Iberian Peninsula, Hill-Fort, Roman common pottery.

\section{INTRODUCCIÓN}

En este artículo presentamos los resultados del estudio llevado a cabo sobre distintas colecciones cerámicas de varias zonas del castro de Viladonga. El objetivo principal de este trabajo es intentar aclarar la evolución cronológica del castro mediante los datos que proporciona el análisis del material cerámico, la información estratigráfica y la documentación existente acerca de otros materiales que se han encontrado en esas zonas y que se pueden usar como indicador cronológico.

Este trabajo se inscribe dentro del marco de un proyecto de investigación más amplio en el que se examina el proceso de "romanización" que sufrió el noroeste peninsular a través del estudio de la cerámica común romana. El castro de Viladonga se adecúa a los propósitos de esta investigación tanto por el ingente volumen de restos recogidos en él, como por el hecho de que, a pesar de ser uno de los yacimientos más visitados por el público y más citados en el ámbito de la divulgación, sus materiales apenas habían sido estudiados.

\section{EL CASTRO DE VILADONGA}

El castro de Viladonga (Fig. 1) se encuentra en Castro de Rei, $23 \mathrm{~km}$ al noroeste de la ciudad de Lugo. Situado a $500 \mathrm{~m}$ de altitud sobre una colina, ocupa una extensión aproximada de unos $40.000 \mathrm{~m}^{2}$ de los cuales 10.000 pertenecen al recinto central. Cuenta con un complejo sistema defensivo formado por varias líneas de parapetos y fosos. Se han diferenciado dos supuestas zonas de expansión (Arias Vilas, 2000: 188) y un recinto central, donde se localizan la mayoría de las estructuras. 


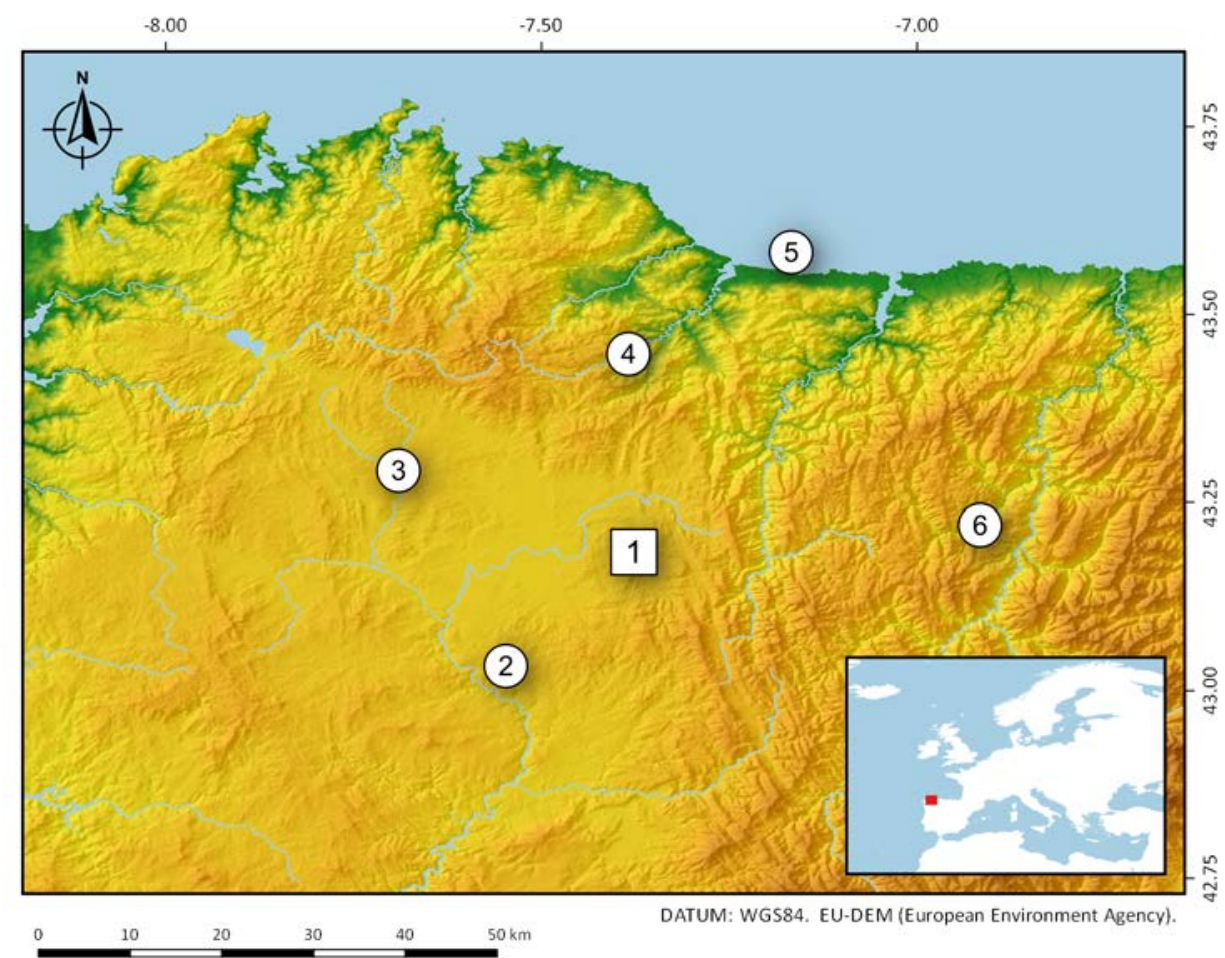

Fig. 1. Situación de los yacimientos citados en el texto. 1.- Castro de Villalonga; 2.- Lucus Augusti; 3.- Castro de Vixil; 4.- Castro de Zoñán; 5.- Punta do Castro; 6.- Castro del Chao de Samartín.

Este yacimiento ha sido frecuentemente excavado a lo largo de los años. Las primeras excavaciones se inician en la década de los setenta y fueron dirigidas por Manuel Chamoso Lamas hasta 1978, etapa en la que fueron exhumadas la mayoría de las estructuras del asentamiento. En 1982, ya bajo la dirección de Felipe Arias Vilas se retoman los trabajos que continuarían hasta la actualidad de la mano de varias empresas. En base a las estructuras encontradas y los materiales analizados -en su mayoría procedentes de las excavaciones de Chamoso- este asentamiento ha sido enmarcado entre finales del s. II y el s. V d.C. por Felipe Arias (2000: 189), a excepción de unos supuestos niveles más antiguos situados en la zona noreste del recinto (Arias Vilas et alii, 2016: 23).

Aunque no se han realizado tantas publicaciones sobre este lugar como cabría suponer, contamos con varios informes acerca de las excavaciones realizadas en las distintas zonas del yacimiento (Arias Vilas, 1985, 1991 y 1996), así como trabajos de restauración de estructuras (Buceta et alii, 2011), 
existen varios estudios edafológicos (Ramil Rego et alii, 1992), faunísticos (Fernández Rodríguez, 2002), estudios puntuales sobre vidrios (Da Cruz, 2007), bronces (Durán Fuentes, 1994) y fusayolas (Pérez Rozas, 2017), así como un catálogo de monedas (Durán Fuentes, 2008/2009) y otro de fíbulas (Lage Pillado, 2004). Las más escasas, sorprendentemente, son las publicaciones sobre los materiales cerámicos. Más allá de un artículo sobre la terra sigillata (Caamaño Gesto et alii, 1984) y otro sobre las paredes finas (Vila Martínez, 1994), sólo se han publicado de manera puntual estudios sobre aspectos concretos como los patrones decorativos (Dorrego et alii, 1998), las asas (Dorrego et alii, 2001) o los grafitos (Durán Fuentes et alii, 1992). Recientemente, ha visto la luz también un breve artículo sobre las cerámicas consideradas más tardías (Tejerizo et alii, 2018).

\section{OBJETIVOS Y METODOLOGÍA}

El propósito de este artículo es el de aclarar la secuencia evolutiva del castro de Viladonga usando como referencia los resultados de la clasificación tipológica de la cerámica común. Trataremos de identificar las distintas producciones y tipos formales presentes en el castro y estableceremos comparaciones con la cerámica de zonas próximas, como la ciudad de Lugo (Alcorta, 2001), otros castros de la costa lucense (Ramil et alii. 1995, Lozano et alii, 2015) o del occidente asturiano (Hevia et alii, 1999 y 2009).

Tras recoger toda la información existente acerca del yacimiento en informes y memorias de excavación y teniendo en cuenta los diferentes trabajos realizados hasta la fecha, seleccionamos aquellas zonas que podrían, a nuestro juicio, ofrecer un mayor conocimiento sobre la evolución diacrónica de la ocupación (fig. 2). Escogimos cinco zonas intentando que fuesen representativas de la totalidad del yacimiento, atendiendo a su ubicación espacial, cronología estimada, potencia estratigráfica y volumen de materiales.

Elegimos la zona noreste del recinto central por ser dónde se localizaron los supuestos niveles prerromanos. También varios cuadros en el sistema defensivo situado al este, con la intención de aclarar la existencia o no de una ocupación anterior a la construcción de estos sistemas defensivos. A través del estudio de las zonas sudeste y sudoeste del recinto central esperábamos caracterizar el nivel correspondiente a la cronología que suele atribuirse al asentamiento. Por último, la zona de expansión situada al oeste debía servirnos como referencia del último momento de ocupación en el que se habitan espacios más allá del recinto central.

Como veremos pormenorizadamente más adelante, existen problemas con el registro estratigráfico llevado a cabo en las distintas campañas de Viladonga, 
acusando a menudo una falta de rigor que obstaculiza el estudio de materiales y siendo inexistente para las excavaciones más antiguas, es decir, para la mayor parte de los materiales recuperados.

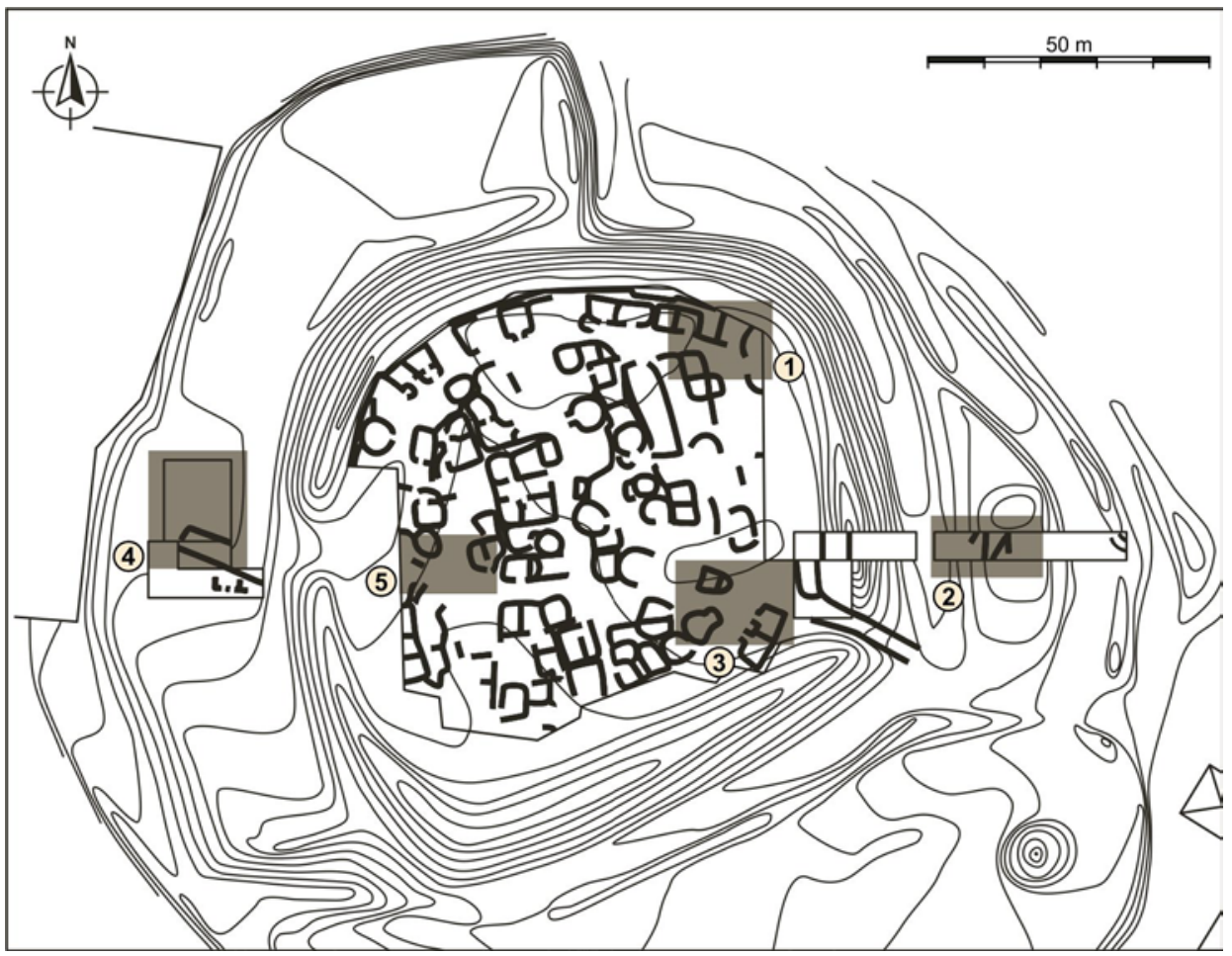

Fig. 2. Situación de las zonas analizadas citadas en el texto (modificado a partir de Arias Vilas et alii, 2016: 21). 1.- Zona noreste; 2.- Zona este del sistema defensivo; 3.- Zona sudeste; 4.- Zona de expansión oeste; 5.- Zona sudoeste.

Para realizar el estudio de la cerámica hemos empleado una metodología clásica dentro de este tipo de trabajos (Ramil Rego, 2010). Tras una exhaustiva recogida de datos, selección, dibujo y fotografía de las piezas se ha establecido una clasificación tipológica preliminar basada en la tipología de referencia que tenemos para el noroeste, la de la cerámica común lucense (Alcorta, 2001). Sin embargo, existe otra producción apenas contemplada en este catálogo y que en Viladonga supone una parte significativa de la muestra. Se trata de una cerámica considerada de producción local o regional, a menudo puesta en relación con la cerámica anterior a la conquista romana, que ha recibido distintos nombres a lo largo de los años en la bibliografía: de tradición indígena, 
de tradición astur, castreña, castreño-romana, etc. (Hevia et alii. 2009: 29). No obstante, a menudo tras un mismo término se ocultan realidades diferentes para distintos autores, no siendo fácil determinar en cada caso qué se incluye o excluye dentro de este grupo y por qué.

Nosotros la denominamos de manera genérica "cerámica nativa", en un intento por evitar la confusión que implicaría la utilización de un vocablo ya existente con un sentido diferente y optando por un nuevo término en lugar de por una resignificación. Sin embargo, somos conscientes de que el problema sobre su denominación no queda resuelto pues haría falta alcanzar un consenso.

De este modo, cerámica nativa sería toda aquella cerámica que conserva las características formales y tecnológicas previas a la llegada de Roma a este territorio. Sin embargo, nuestro grado de conocimiento sobre las características de las producciones prerromanas es limitado (Ramil Rego, 1997). Lo cierto es que no son demasiados los trabajos que se han realizado hasta el momento en castros del entorno de Viladonga, por lo que es poca la información de la que disponemos para poder contrastar estos datos. En muchos casos, la aparición de esta producción ha bastado para otorgar una cronología antigua a los yacimientos, no siendo adecuada esta inferencia.

Componen la cerámica nativa piezas hechas a mano o a torno lento, con pastas negras, grises o marrones, con abundantes desgrasantes de mica y cuarzo. La cocción suele ser irregular, mostrando un mismo fragmento distintas estructuras cromáticas en su fractura. La coloración de las superficies oscila entre marrones, naranjas, ocres, negras o gris oscuro, presentando, en escasas ocasiones, un gris claro. El tratamiento de las superficies se hará con someros alisados, presentando a menudo la superficie exterior acabados más cuidados, existiendo, en ocasiones, un bruñido continuo.

A pesar de que existe una gran homogeneidad morfotecnológica en casi toda la cerámica nativa, dentro de esta producción separamos un subgrupo que difiere ligeramente. Estas piezas presentan pastas oscuras con menor presencia de desgrasantes que el resto de la cerámica nativa, un tratamiento superficial más cuidado con frecuentes bruñidos y cepillados, especialmente en la cara interna del cuerpo. Sus formas difieren de las habituales, constatándose una mayor variabilidad respecto al resto de la cerámica nativa, con tipos definidos y normalmente adscritos a época altoimperial.

La cerámica común romana no está tampoco exenta de problemas metodológicos. Es una producción a veces considerada "un cajón de sastre" (Huguet Enguita, 2013: 293) por los investigadores debido a que se suele incluir en ella todo lo que no encaja dentro de otras producciones mejor conocidas, como la terra sigillata, las paredes finas, o las ánforas. Además, por su carácter cotidiano, está fuertemente influenciada por los gustos locales y por las tradiciones alfareras anteriores, no distinguiéndose, en muchos casos, donde 
acaban unas y empiezan otras. El catálogo de referencia para la zona de Lugo (Alcorta, 2001), aunque es de indispensable uso, en ocasiones presenta una clasificación tipológica ambigua debido al uso de criterios como la decoración o la presencia de asa como marcadores tipológicos lo que, si tenemos en cuenta la alta fragmentación que existe en todas estas colecciones, dificulta mucho las tareas de clasificación. Además, la mayoría de estos tipos presentan una adscripción cronológica muy amplia, lo que merma su utilidad a la hora de concretar la evolución diacrónica de las ocupaciones.

Por todo esto, aunque de momento emplearemos estos términos para identificar y clasificar la cerámica de Viladonga, aclaramos que, habida cuenta de todos los problemas metodológicos que presentan, la definición de estas producciones se encuentra ahora mismo en proceso de revisión, no descartándose posibles cambios en el futuro en torno a esta clasificación.

\section{RESULTADOS DEL ESTUDIO DE MATERIALES}

Nos hemos ceñido al estudio de la cerámica procedente de varios cuadros excavados desde los años setenta hasta 1992 en la zona noreste del recinto central y en 1988 y 1989 en la zona este del sistema defensivo, que eran los lugares donde la documentación administrativa señalaba la existencia de unos niveles anteriores a la llegada de Roma. Seguidamente, hemos estudiado la cerámica procedente de otras zonas del castro asociadas a la cronología que habitualmente se le da a este asentamiento, en concreto la de las excavaciones realizadas en 1996 y 2016 en el sudoeste y sudeste del recinto central y en la zona de expansión oeste.

\section{1. Zona noreste del recinto central (Años 70, 1983, 1984 y 1992)}

Desde 1971 a 1978 se excavó la mayor parte del recinto central del castro, dejando testigos que fueron retirados en 1983 (Arias Vilas, 1985), incluida la zona noreste, que es la que hemos seleccionado para la primera parte del estudio por su mayor potencia estratigráfica. Durante la campaña de 1984 se continuó y amplió la excavación de esta zona, documentándose bajo las construcciones situadas en los cuadros I-25, I-46 e I-47 (Fig. 3) niveles a mayor profundidad que describimos a continuación. 


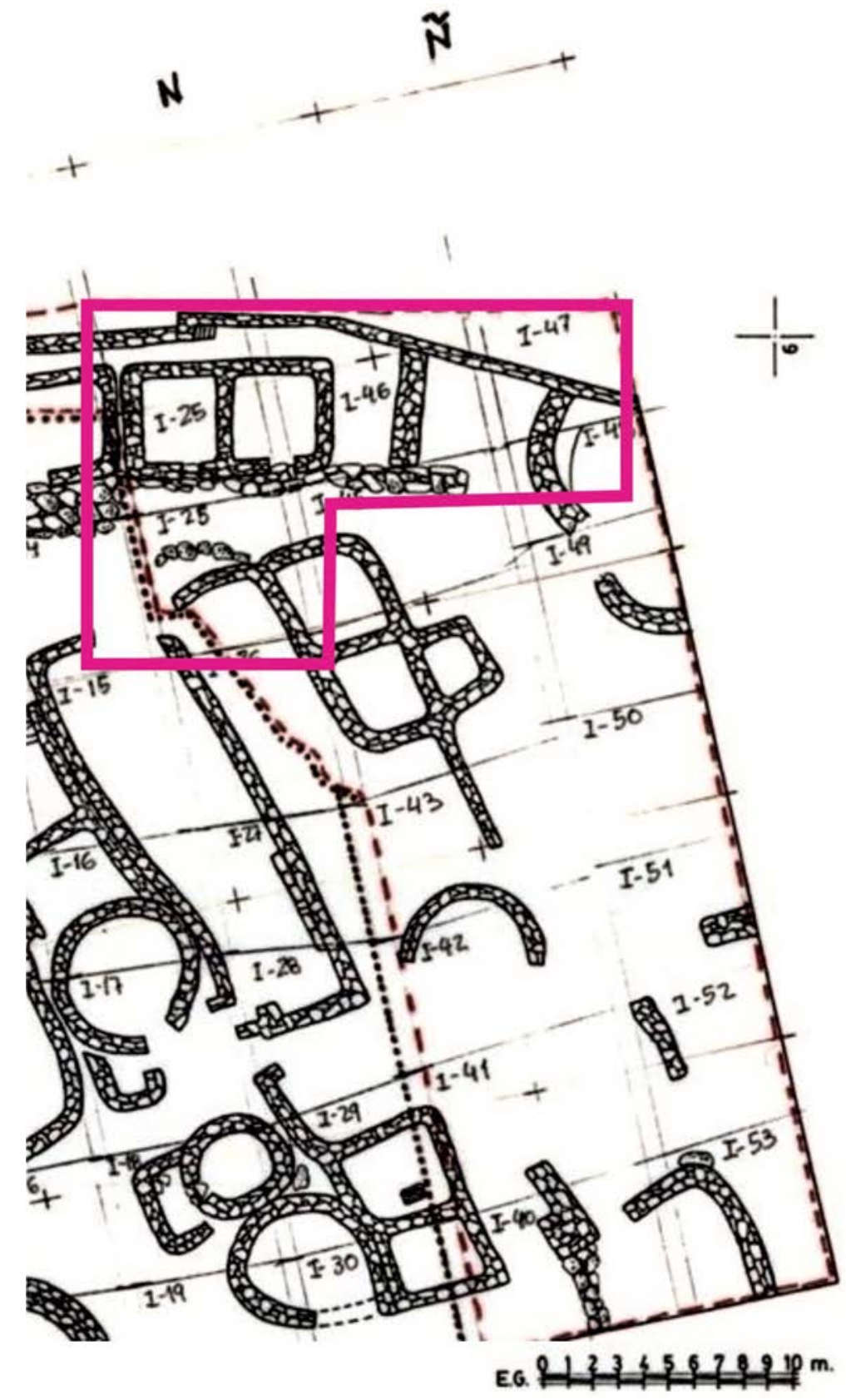

Fig. 3. Plano de la zona noreste del recinto central con los cuadros estudiados (modificado según Arias Vilas, 1987). 
El cuadro I-25 resultó tener una potencia arqueológica mayor de la que se había pensado en un principio (Arias Vilas, 1987: 3). Por debajo del nivel dejado en los años 70, se documentó "...una sucesión de pisos de barro, ou camas dos mesmos, en xeral moi localizados e as veces con sinais de lareiras..." (Arias Vilas, 1987: 3) también se localizó una "pedra de quicieira de porta, de pizarra, a uns $60 \mathrm{~cm}$ por baixo do nivel correspondente á porta da vivenda que se conserva actualmente.” (Arias Vilas, 1987: 3) En el corte oeste de este mismo cuadro se documentó lo siguiente:

“...un muro de sillarexo de pizarra pouco consistente, sito entre 70-110 cm por baixo do nivel actual do Castro y cunha extensión desigual e polo tanto aproximada, duns dous metros.” (Arias Vilas, 1987: 3).

En los cuadros I-46 y I-47 se observó que “...o firme natural [...] estaba aínda a considerable fondura...” (Arias Vilas, 1987: 4). El cuadro I-47 presentó las siguientes características:

“...un tramo de muro circular, ben paredado polo exterior [...] e sito por baixo daquel nivel de cimentación da muralla principal e, polo tanto, anterior, ou sexa correspondente a un nivel de ocupación nunca posterior ó s. III d.C.” (Arias Vilas, 1987: 4).

En la documentación consultada se plantea una posible ocupación anterior para estos niveles:

“...non se descarta a hipótese de que nesta parte do Castro, se dese un certo tipo de ocupación temporal, ben nun momento propiamente prerromano [...] ben nun momento mesmamente anterior ó s. III d.C”. (Arias Vilas, 1987: 10).

Posteriormente, en la campaña del 1992, se eliminaron los testigos dejados en la campaña de 1984 y se profundizó. La excavación permitió comprobar en los testigos N-8, Ñ-8 y Ñ 8/9 situados en la zona noreste, la existencia de “...un nivel de ocupación muy desfeito e entullado, anterior ó do hábitat principal (tardío) do Castro” (Arias Vilas, 2000: 193). Se localizaron restos de “...dous muretes moi desfeitos por baixo da cimentación das construcciones hoxe visibles..." (Arias Vilas, 2000: 193). En base a esto y los materiales encontrados, descritos como "cerámica de tradición castrexa, lisa, ruin e moi esnaquizada” (Arias Vilas, 2000: 195) los excavadores propusieron para estos niveles una cronología anterior al cambio de era, entre el s. II a.C. y el I a.C. (Arias Vilas et alii, 2016: 67). 


\section{1. 1. Cerámica nativa de la zona noreste del recinto central}

Si tenemos en cuenta el conjunto de la muestra analizada podríamos considerar esta como la producción predominante en esta zona. Presenta una acusada fragmentación que no ha sido compensada con un esfuerzo para la reintegración de fragmentos, por lo que el escaso desarrollo de los perfiles ha dificultado su análisis morfológico, no existiendo perfiles completos.

Dentro de las piezas que hemos seleccionado para su identificación formal, el conjunto más representado es el de las ollas. Respecto a su tamaño, las ollas medianas (15-30 cm de diámetro de borde) abundan respecto a las grandes (30$50 \mathrm{~cm}$ de diámetro de borde) y las pequeñas $(12-15 \mathrm{~cm})$.

Dentro de las ollas, diferenciamos un primer grupo morfológico (Fig. 4, 17), caracterizado por presentar un borde oblicuo abierto o cóncavo acabado en un labio plano o redondeado que se une directamente a un cuerpo convexo. Incluimos aquí un par de ejemplos en los que el borde muestra un facetado interior (Fig. 4, 3) y un subgrupo de ollas (Fig.4, 4) con un labio con un ligero engrosamiento hacia el exterior, demasiado pequeño como para ser considerado un borde con desplazamiento horizontal abierto.

En este primer grupo morfológico podríamos destacar otro subgrupo de ollitas de aproximadamente $15 \mathrm{~cm}$ de diámetro de borde (Fig. 4, 5-7), dentro del cual resaltamos una ollita con decoración estampillada en la cara externa del cuerpo (Fig. 4, 7), idéntica al tipo L13 de Lugo (Alcorta, 2001: 115, fig. 50).

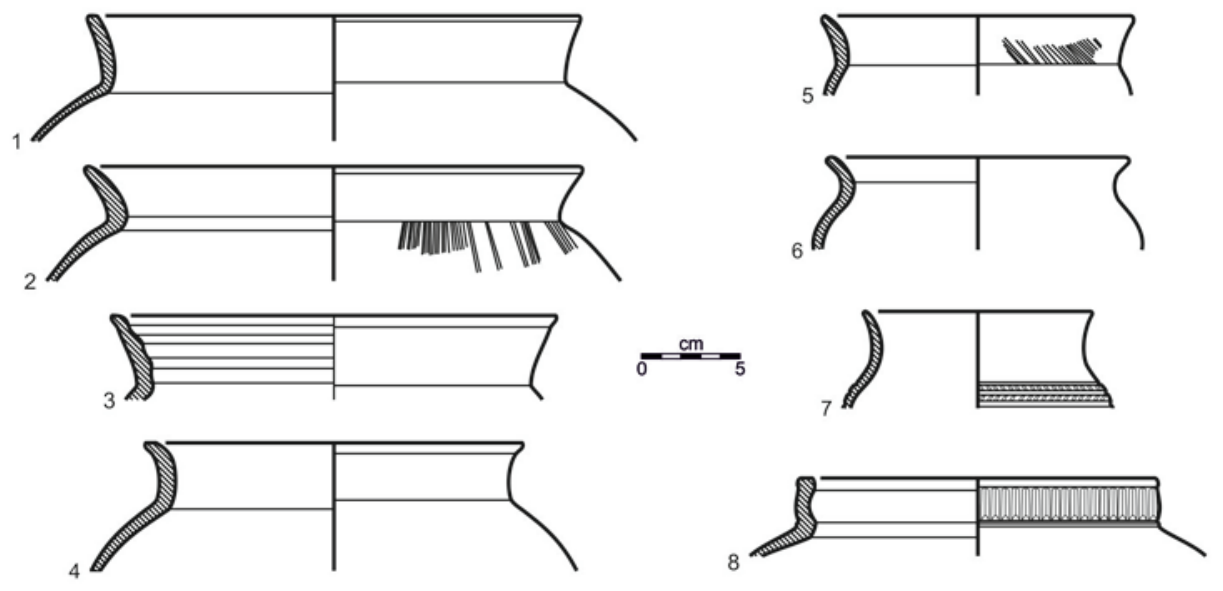

Fig. 4. Cerámica nativa de la zona noreste. Ollas (1-8). 
Un segundo grupo de ollas (Fig. 5, 4) vendría definido por un labio redondeado al que le sigue un borde con desplazamiento horizontal abierto (con una longitud que varía notablemente entre una pieza y otra) o un borde oblicuo poco desarrollado; estos bordes se unen, a través de un cuello cóncavo oblicuo cerrado, a un cuerpo convexo, pero esta unión no está marcada de forma neta, sino que se desarrolla progresivamente.

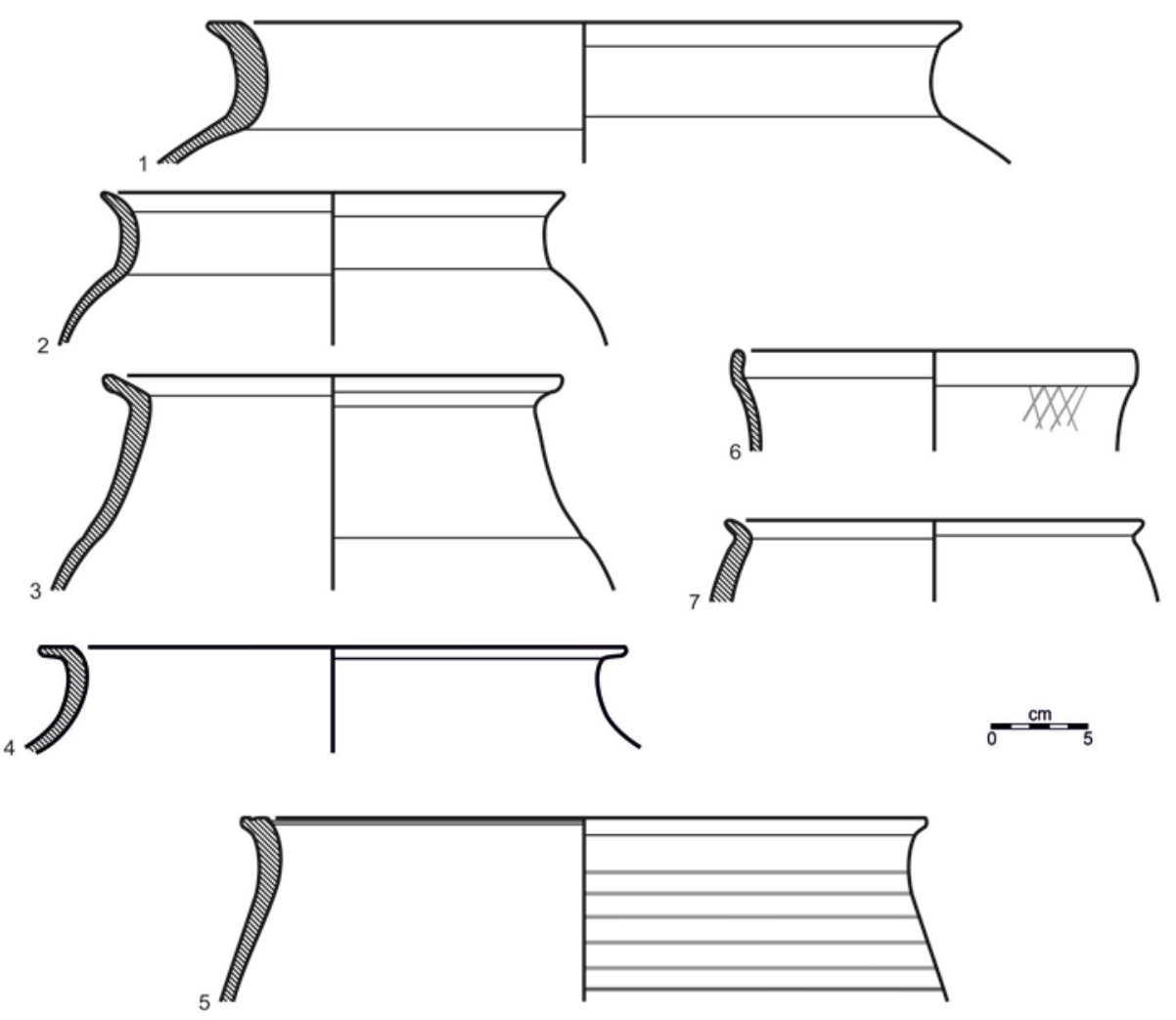

Fig. 5. Cerámica nativa de la zona noreste. Ollas (1-7).

Por último, identificamos un tercer grupo (Fig. 5, 2-3) en el que incluimos todas las piezas con labio redondeado, borde oblicuo abierto escasamente desarrollado o borde cóncavo, seguido por un cuello cóncavo oblicuo abierto o cerrado de longitud variable que se une a un cuerpo convexo mediante una inflexión neta. 
En estos tres grupos, la decoración se darán como algo residual, en forma de bruñidos verticales u oblícuos en la cara externa del borde o del cuerpo, y algún acanalado en la cara externa del cuerpo.

Además de estos grupos formales, donde situamos la mayor parte de la colección estudiada, se han documentado otras formas, menos representadas, pero que merecen ser tenidas en cuenta, como por ejemplo un conjunto de ollas (Fig. 4, 8) caracterizadas por una compleja decoración plástica en la cara externa del borde realizada a través de una sucesión de impresiones de un cuerpo semicilíndrico hueco, probablemente algún tipo de cánula cortada. Este borde se caracteriza por ser de desplazamiento horizontal cerrado o bilateral, acabado en labio plano o redondeado y seguido por un cuello y cuerpo convexo.

Asimismo, hemos identificado unos recipientes que, por el tamaño de sus diámetros superiores, de más de $30 \mathrm{~cm}$, son considerados de grandes dimensiones (Fig. 5, 1), sin embargo, su escaso perfil no permite decir mucho más aparte de que poseen unas paredes muy gruesas, un labio plano y un borde ligeramente curvado abierto.

Como ejemplares únicos en esta zona documentamos una pieza (Fig. 5, 5) con un pequeño borde oblicuo, cuello cóncavo poco desarrollado que se une, sin una inflexión marcada, a un cuerpo que pudiera ser convexo. Este recipiente presenta una decoración hecha a base de líneas paralelas horizontales bruñidas en la cara externa del cuerpo. Otro ejemplar único presenta un borde recto y cuello cóncavo, con decoración de retícula bruñida en la cara externa del cuello (Fig. 5, 6). Un tercero presenta un borde oblicuo muy pequeño y cuerpo convexo, pero no encaja en ninguno de los grupos anteriores (Fig. 5, 7).

Los cuencos son el segundo conjunto más importante dentro de la cerámica nativa de esta zona, aunque son pocos en comparación con las ollas. En esta colección predominan los que poseen un borde con desplazamiento horizontal cerrado acabado en labio redondeado o plano y cuerpo convexo o convexo oblicuo abierto (Fig. 6, 4-7), exceptuando una pieza con borde con desplazamiento horizontal abierto (Fig. 6, 3). Asimismo, hay que mencionar un par de ejemplos caracterizados por un labio engrosado seguidos de un cuerpo que parece ser convexo (Fig. 6, 6). Los diámetros de sus bordes van de los 17 a los $36 \mathrm{~cm}$. Muchos de estos cuencos poseen decoración, la más frecuente es la impresión de motivos espigados en la parte superior del labio (Fig. 6, 4). En un único caso se observa una decoración de líneas incisas onduladas en la parte superior externa del cuerpo (Fig. 6, 6), y en otro un cordón con líneas incisas oblicuas (Fig. 6, 7) situado bajo una línea horizontal incisa. 

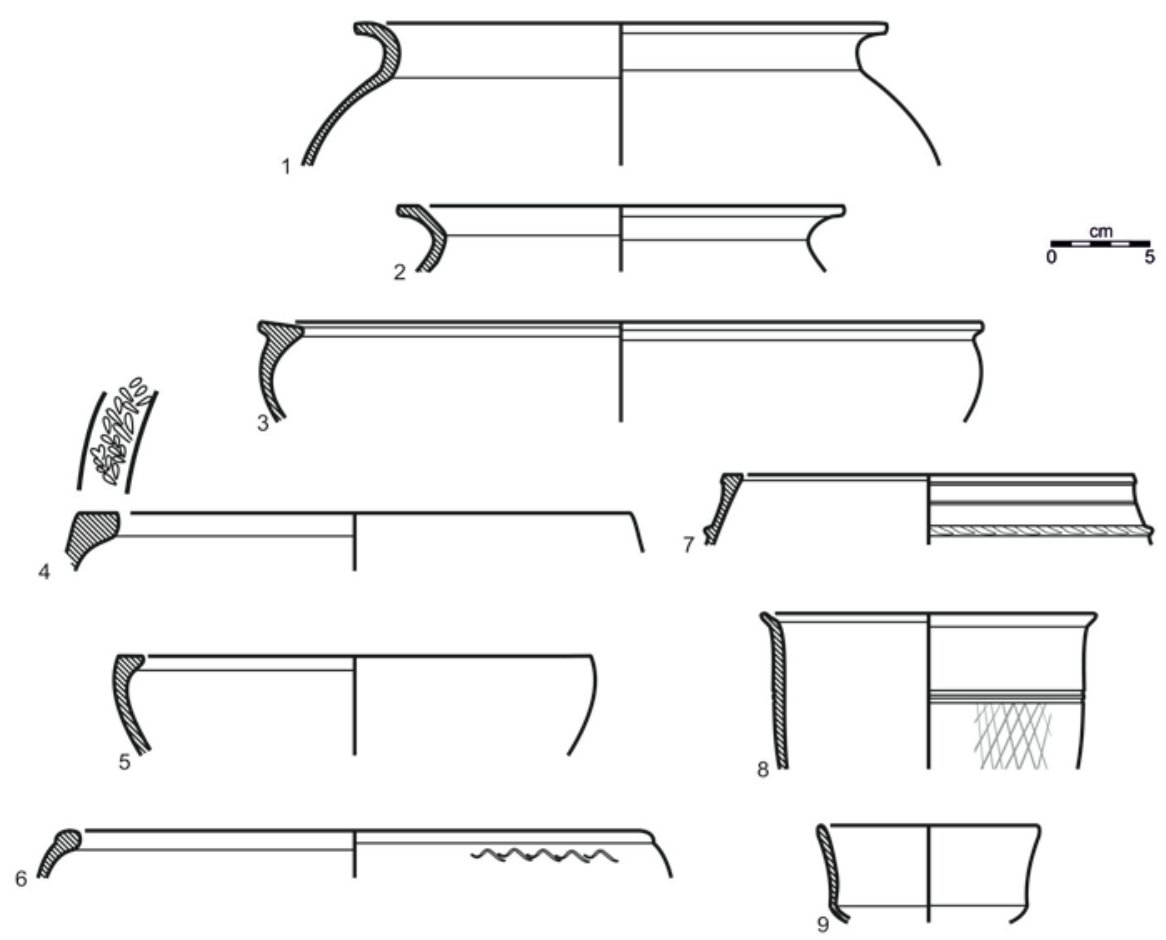

Fig. 6. Cerámica nativa de la zona noreste. Cuencos (1-5), ollas (6-7), vaso (8) y taza (9).

Dentro del subgrupo de piezas nativas que diferenciábamos en la metodología por su acabado más cuidado, escasez de desgrasantes y mayor variabilidad formal, identificamos ollas caracterizadas por un pequeño borde oblicuo o con desplazamiento horizontal abierto, cuello oblicuo y cuerpo convexo (Fig. 6, 1-2) que se podrían relacionar con las L1 y las L4 de Alcorta para Lugo (Alcorta, 2001: 81-97) si pudiésemos confirmar su decoración. Estas piezas tienen unas dimensiones que varían entre los 17 y los $36 \mathrm{~cm}$ para el diámetro de borde. El escaso desarrollo de los perfiles de la muestra no ha permitido constatar si poseen la decoración que caracteriza a las L1 y las L4, pero encontramos paralelos con las ollas lisas de borde facetado del Chao Samartín (Hevia et alii, 2009: 88-89, fig. 72), de similares características morfotecnológicas y cronología que las de Lugo, pero sin el requisito de la decoración como marcador tipológico.

Otro tipo identificado es un vaso o "tazón monoansado con decoración" (Fig. 6, 8), tipo L16 (Alcorta, 2001: 122-123, fig. 54) caracterizado por tener labio redondeado, un pequeño borde oblicuo con un diámetro de $17 \mathrm{~cm}$ y cuerpo 
convexo poco desarrollado, así como una decoración de líneas bruñidas oblicuas que conforman un motivo reticulado en la cara externa del cuerpo, situada bajo dos líneas espatuladas horizontales.

También se han documentado dos pequeñas piezas de recipientes con labio redondeado, borde ligeramente cóncavo y alargado separado de un cuerpo, que parece convexo oblicuo abierto, por una carena no muy marcada (Fig. 6, 9). Tienen entre 10 y $11 \mathrm{~cm}$ de apertura de borde y pueden relacionarse con las tazas carenadas monoansadas del castro del Chao Samartín (Hevia et alii, 2009: 51, fig. 35) aunque debido a las pequeñas dimensiones de los fragmentos analizados, no se ha podido constatar la presencia de asa.

\section{1. 2. Cerámica común romana de la zona noreste del recinto central}

En primer lugar, estudiamos el grupo de las ollas, uno de los más representados dentro de la cerámica común romana. Estas ollas (Fig. 7) están caracterizadas por un borde oblicuo o cóncavo unido a un cuerpo convexo coincidiendo con el tipo O1 (Fig. 7, 2), O2 (Fig. 7, 3) y O24 (Fig. 7, 7) de Lugo (Alcorta, 2001: 193-198, fig. 80-82, 250, fig. 105). Existen algunas variaciones formales, como las ollas con borde triangular (Fig. 7, 6) tipo O7 (Alcorta, 2001: 207-209, fig. 88) que han sido relacionadas con el fenómeno de expansión de las ollas de cerámica común no torneada de difusión aquitano tarraconense o CNT-AQTA (Esteban et alii, 2008).
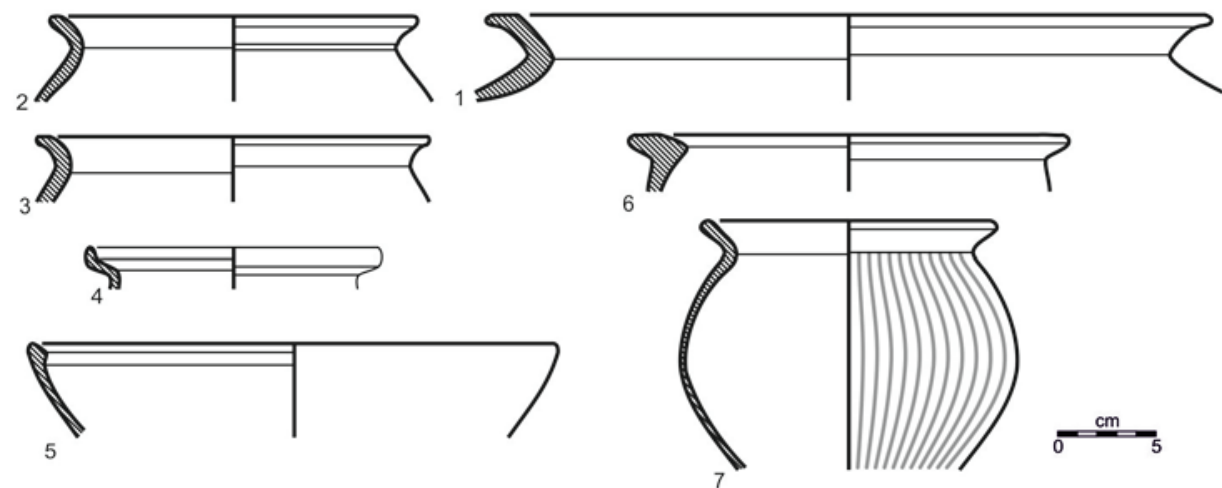

Fig. 7. Cerámica común romana de la zona noreste. Ollas (1-4 y 6-7) y cuenco (5). 
Las ollas de cerámica común de esta zona presentan unas dimensiones de 10 a $30 \mathrm{~cm}$ de diámetro de borde y apenas tienen decoración, a excepción de algunas acanaladuras horizontales bajo el borde y líneas bruñidas verticales en la cara externa del cuerpo en el caso de algunas ollitas tipo O24 (Fig. 7, 7).

Sin poder precisar su tipo, documentamos una olla de borde oblicuo de grandes dimensiones, $36 \mathrm{~cm}$ de apertura de borde (Fig. 7, 1), que podría corresponderse con las O12 de Lugo (Alcorta, 2001: 223-226, fig. 94) pero el escaso desarrollo de su perfil impide afirmarlo con seguridad. También se ha documentado una pieza con borde con desplazamiento horizontal abierto con una concavidad en la parte superior interna del borde (Fig. 7,4$)$ que, por sus dimensiones y forma podría tener su paralelo con las O3 de Lugo (Alcorta, 2001: 199-200, fig. 83), aunque de nuevo, su insuficiente desarrollo no ha permitido ir más allá.

Dentro del grupo de los cuencos, hemos identificado un tipo caracterizado por un cuerpo convexo oblicuo abierto rematado con un labio de superficie plana u oblicua ligeramente engrosado hacia el interior (Fig. 7, 5), forma relacionada con los C3 de Lugo (Alcorta, 2001: 331-333, fig. 139). Oscilan entre los 21 y $34 \mathrm{~cm}$ de diámetro de borde y carecen de decoración. Resaltamos cuatro piezas que presentan pastas y superficies naranjas, difiriendo del habitual color gris de este tipo.

Se ha estudiado un conjunto de piezas que identificamos como jarras (Fig. 8, 1-3). De pequeñas dimensiones, con diámetros de apertura de borde de entre 6 y $10 \mathrm{~cm}$. En primer lugar, hemos documentado un conjunto de jarras (Fig. 8, 1) tipo J1 (Alcorta, 2001: 279-282, fig. 117) de borde oblicuo poco desarrollado acabado en un labio redondeado, seguido de un cuello ligeramente cóncavo y alargado continuado por el cuerpo convexo sin ningún tipo de inflexión, uno de ellos tiene un asa de sección oval que parte de la cara superior del borde hasta la zona media del cuerpo, y carecen de decoración.

En segundo lugar (Fig. 8, 2-3) tenemos unos recipientes de borde oblicuo acabado en labio redondeado, cuello convexo y asa de sección ovalada que parte de la zona media del cuello. Se caracterizan por unas pastas color siena o naranja claro con abundantes desgrasantes en superficie y carecen de decoración. La superficie se encuentra muy desgastada, por lo que no podemos saber si tuvieron engobe o no o qué tipo de tratamiento superficial recibieron. Debido a la falta de un perfil más desarrollado y su mala conservación, no es imposible adscribirlas a ningún tipo conocido. 

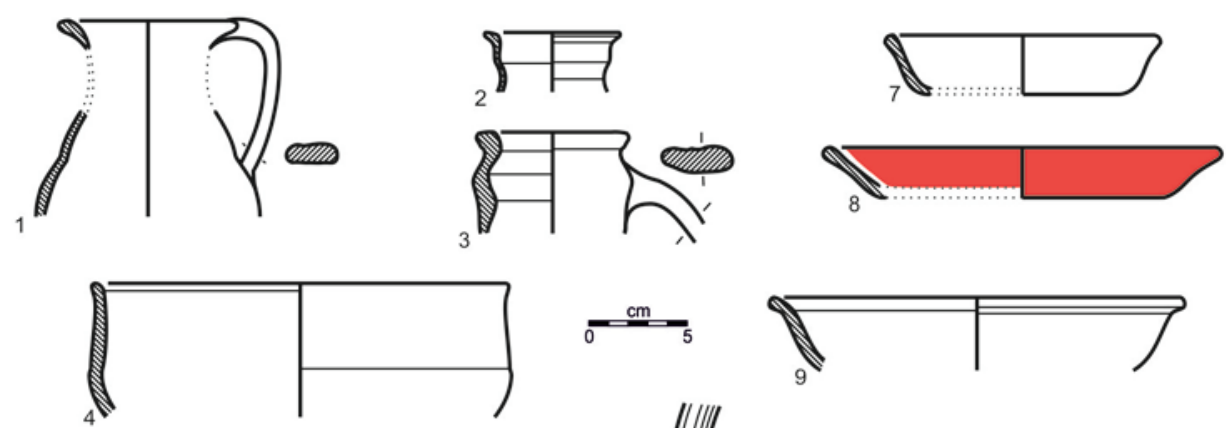

IIIII
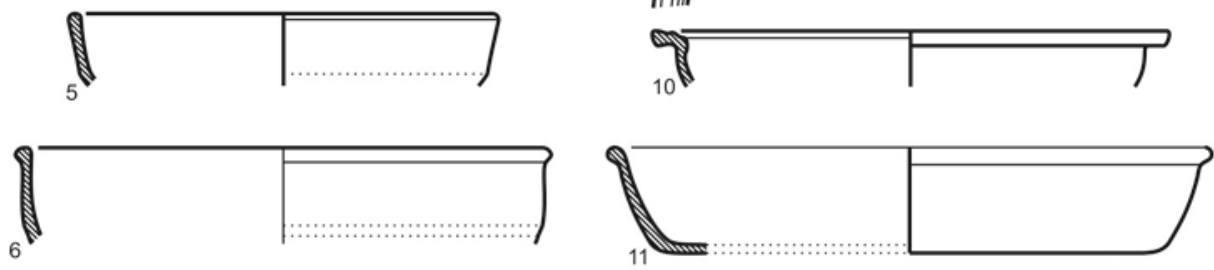

Fig. 8. Cerámica común romana de la zona noreste. Jarras (1-3), platos (7-8) y fuentes (4-6 y 911).

Los platos (Fig. 8, 7-8), representados en menor medida, están caracterizados por un labio redondeado, cuerpo oblicuo y apertura de borde de entre 16 y $20 \mathrm{~cm}$. La mayoría de ellos (Fig. 8, 7) se adscribe a los P1 de pastas grises (Alcorta, 2001: 359-360, fig. 151), el resto, con un engobe rojo en la cara interna y externa del cuerpo (Fig. 8, 8), coincide con los EP3 de Lugo (Alcorta, 2001: 348-350, fig. 146).

Por otro lado, analizamos una fuente con perfil completo (Fig. 8, 11). Esta pieza tiene un labio engrosado y cuerpo oblicuo abierto que acaba en una base plana de $27 \mathrm{~cm}$ de diámetro, coincide con los platos documentados en Lugo por sus características tecnológicas, con pastas de color siena oscuro, abundantes desgrasantes y tratamiento superficial a base de someros alisados, aunque no encaja a la perfección en ningún tipo debido a su morfología.

Además, se ha identificado una fuente tipo EP6 (Alcorta, 2001: 352-354, fig. 148) con una superficie muy desgastada, de borde con desplazamiento horizontal abierto caracterizado por unas acanaladuras en la parte superior del borde, cuerpo oblicuo y diámetro de borde de $30 \mathrm{~cm}$ (Fig. 8, 10) y por último una pieza que podría identificarse como una fuente de borde y cuerpo oblicuo y una apertura de borde de $21 \mathrm{~cm}$ (Fig. 8, 9), presenta unas pastas grises, micáceas, de textura porosa y un cuidado alisado.

Documentamos también un conjunto de recipientes conformados por un labio redondeado o ligeramente engrosado hacia el exterior, seguido de un 
cuerpo convexo oblicuo abierto marcado en la parte inferior por una carena o leve inflexión (Fig. 8, 4-6). Son recipientes fabricados con torno rápido, de cocción reductora u oxidante, pastas grises o anaranjadas con abundantes desgrasantes micáceos en superficie y bien tratadas superficialmente, con cuidados alisados en la cara interna y externa de la pieza. Carecen de decoración. Uno de ellos (Fig. 8, 6), puede clasificarse dentro de las F2 de Lugo (Alcorta, 2001: 342-343, fig. 143) los otros difieren morfológicamente y no encajan en ese tipo.

Otro de los tipos identificados es el de los vasos V2 (Alcorta, 2001: 265270, fig. 112), con unas pocas piezas que conservan el pie y el cuerpo, con un diámetro en la parte central del cuerpo de entre 9 y $11 \mathrm{~cm}$ (Fig. 9, 2), donde también presentan decoración en forma de espatulados horizontales.

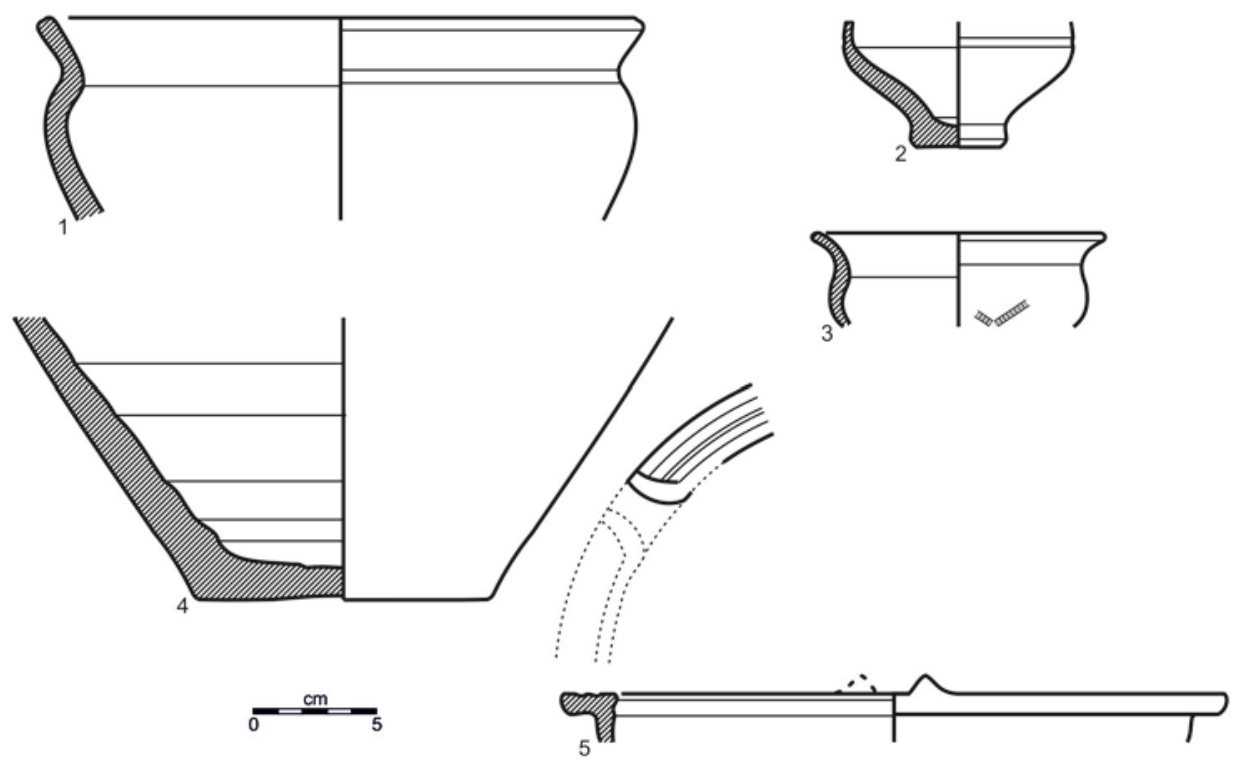

Fig. 9. Cerámica común romana de la zona noreste. Vaso (2), tiesto (4), mortero (5) y otros (1 y $3)$.

Para terminar, hay que mencionar la presencia de un mortero (Fig. 9, 5) de borde con desplazamiento horizontal abierto que conserva su pico vertedor. La parte superior del borde está decorado con acanaladura. Su diámetro de apertura de borde es de $27 \mathrm{~cm}$. De factura tosca, sus pastas son de color ocre y presenta 
abundantes desgrasantes micáceos y cuarcíticos, además de un nulo tratamiento superficial.

También se han documentado un par de piezas de cuerpo y base de grandes dimensiones con pastas de color naranja y abundantes desgrasantes de cuarzo y mica en su superficie, así como acusadas marcas de torno en su cara interna (Fig. 9, 4) que pueden corresponderse con tiestos tipo TR (Alcorta, 2001: 300303, fig. 127) aunque la falta de un perfil más desarrollado impide saberlo con certeza.

Resaltamos dos piezas que, por sus características morfotecnológicas, difieren del resto de la muestra analizada. Por un lado, un cuenco pequeño (fig. 9, 3), de 11,9 cm de diámetro de borde, de borde cóncavo y cuerpo convexo, tiene unas pastas grises micáceas, de textura porosa y un tratamiento superficial cuidado, con decoración impresa a ruedecilla en la cara externa del cuerpo. Por sus características tecnológicas, podemos relacionarla con la cerámica gris tardía de Lugo (Alcorta, 2001: 383) pero no encaja en ninguno de los grupos formales conocidos. Quizás se trate de un recipiente asimilable a algunas formas de la terra sigillata gálica tardía o DSP (Uscatescu et alii, 1994: 208, fig. 12).

Por último, hemos documentado otro cuenco (Fig. 9, 1) de 24,5 cm de diámetro de borde, borde oblicuo y cuerpo convexo, pastas color siena oscuro y alisado cuidado, que recuerda a una Drag. 27, y que se corresponde con el tipo I27 de Lugo (Alcorta Irastorza, E., 2001: 366-368, fig. 154).

\section{2. Zona este del sistema defensivo (1988-1989)}

Entre 1988 y 1989, se realizó un corte transversal en los parapetos y fosos del lado este del yacimiento, documentándose la estructura del sistema defensivo, construido "a base de paramentos de pedra pola cara interior e de moreas de terra e pedra polo lado exterior e sobre candaseu foso" (Arias Vilas et alii, 2003: 197). En los cuadros 12-S/1 y 12-S/4 (Fig. 10), situados entre el segundo y el tercer parapeto, bajo un nivel en el que, según quién lo excavó, se encontraba "un recinto a xeito de corpo de garda aberto cara a entrada Leste do Castro" (Arias Vilas et alii, 2003: 197), se exhumaron restos de algunas estructuras consistentes en "un nivel de barro apisonado e nunha lareira pequena” (Arias Vilas et alii, 2003: 197). Según los excavadores, este nivel sería anterior a la construcción de sistema defensivo (Arias Vilas et alii, 2003: 197). 


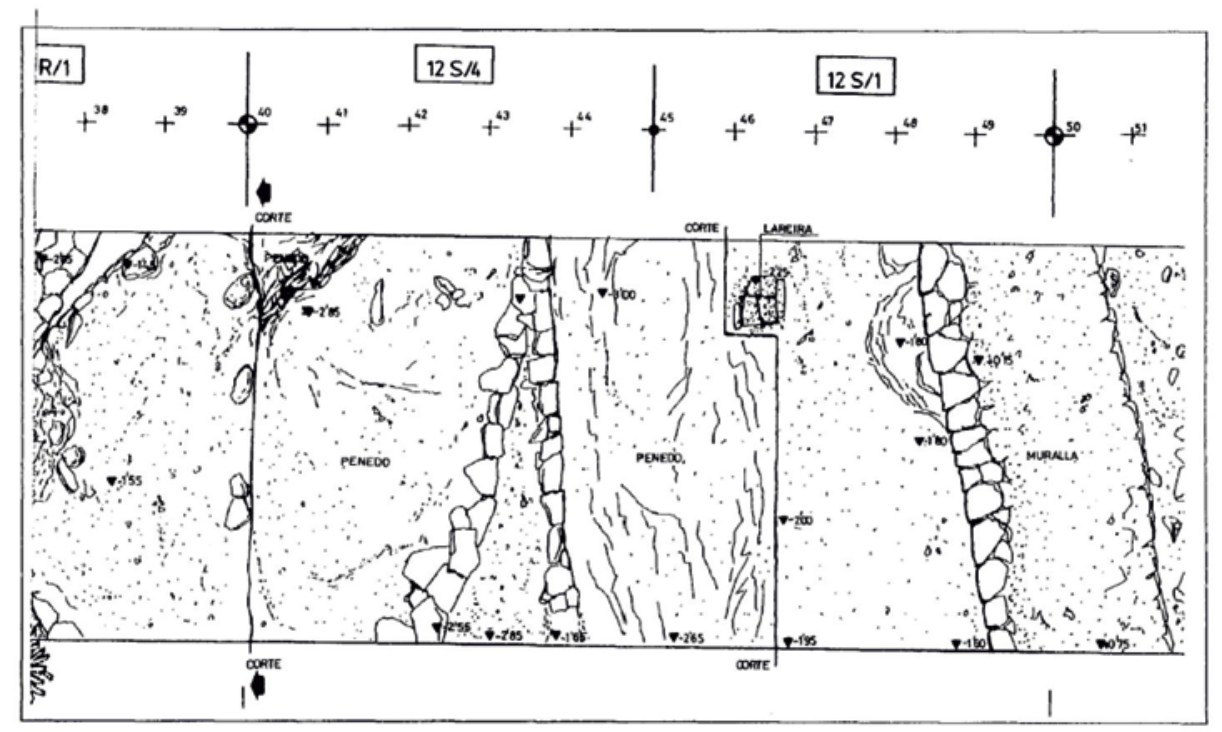

Fig. 10. Planta de los cuadros 12-S/4 y 12-S/1 de la zona este del sistema defensivo (Arias Vilas et alii, 2003).

Durante esta campaña, además, se realizaron dataciones radiocarbónicas sobre varias muestras. La primera (CSIC $n^{\circ}$ 896) se hizo sobre huesos sueltos recogidos “... na parte alta do recheo interior de terra da muralla principal, que cobre o cerne ou nervio pétreo [...] deste primeiro e principal recinto amurallado...” (Arias Vilas et alii, 2003: 198). Las siguientes se realizaron sobre tres carbones vegetales, los dos primeros (CSIS $n^{\circ} 938$ y n $^{\circ}$ 862) tienen una procedencia que se detalla a continuación:

“... concentración de carbóns localizada no espacio que está sobre ou a rentes da segunda muralla, e vinculada a algúns elementos constructivos (restos de pallabarros) e a cerámica castrexa moi común, atípica e esnaquizada” (Arias Vilas et alii, 2003: 198)

Y una tercera muestra de carbón (CSIC nº 861) localizada en:

“...unha lareiriña situada cerca da terceira muralla e nas inmediacións daquela concentración de cinzas a carbóns, e pode asociarse a un solo de barro apisonado que deu alguna cerámica común castrexa como a xa antedita” (Arias Vilas et alii, 2003: 198).

De los resultados de estas dataciones (Fig. 11) se dedujo un nivel de ocupación más antiguo, a grandes rasgos situado entre el S. I a.C. y la segunda década s. I d.C. según Arias Vilas (2000: 192). 


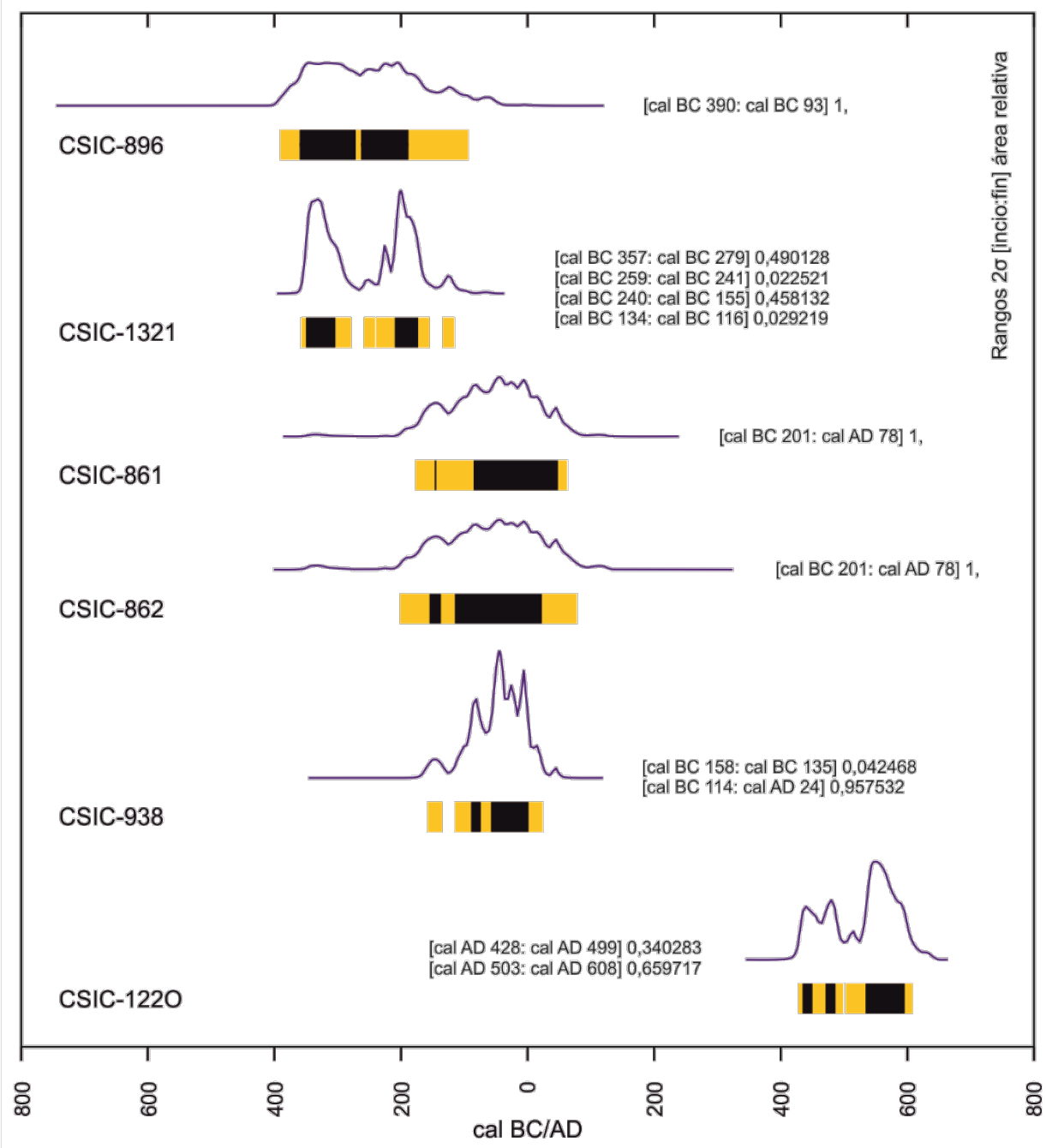

Fig. 11. Dataciones radiocarbónicas obtenidas para el yacimiento calibradas a $2 \sigma$ (Stuvier y Reimer, 1993)

\section{2. 1. Cerámica nativa de la zona este del sistema defensivo}

La producción nativa es la única que hemos documentado en esta zona. Al igual que en la zona noreste, el conjunto de las ollas se presenta como el más abundante. Respecto a su morfología, predominan los bordes oblicuos y los cuerpos convexos, y son frecuentes las ollas medianas (15-25 cm de diámetro de borde) respecto a las grandes y las pequeñas. Encontramos aquí los mismos 
grupos formales que describíamos en el apartado anterior, con las mismas características morfotecnológicas y decorativas (Fig. 12).

Destacamos una olla de borde oblicuo, cuerpo convexo y asa de sección rectangular partiendo del labio (Fig. 12, 4) y un conjunto de recipientes de difícil adscripción con labio redondeado, borde oblicuo muy corto y poco marcado, sin cuello, y con un cuerpo que describe una curva muy poco marcada y casi vertical (Fig. 12, 6) que, a pesar de carecer de decoración, son similares formalmente al recipiente de decoración horizontal bruñida de la zona noreste (Fig. 5, 5).
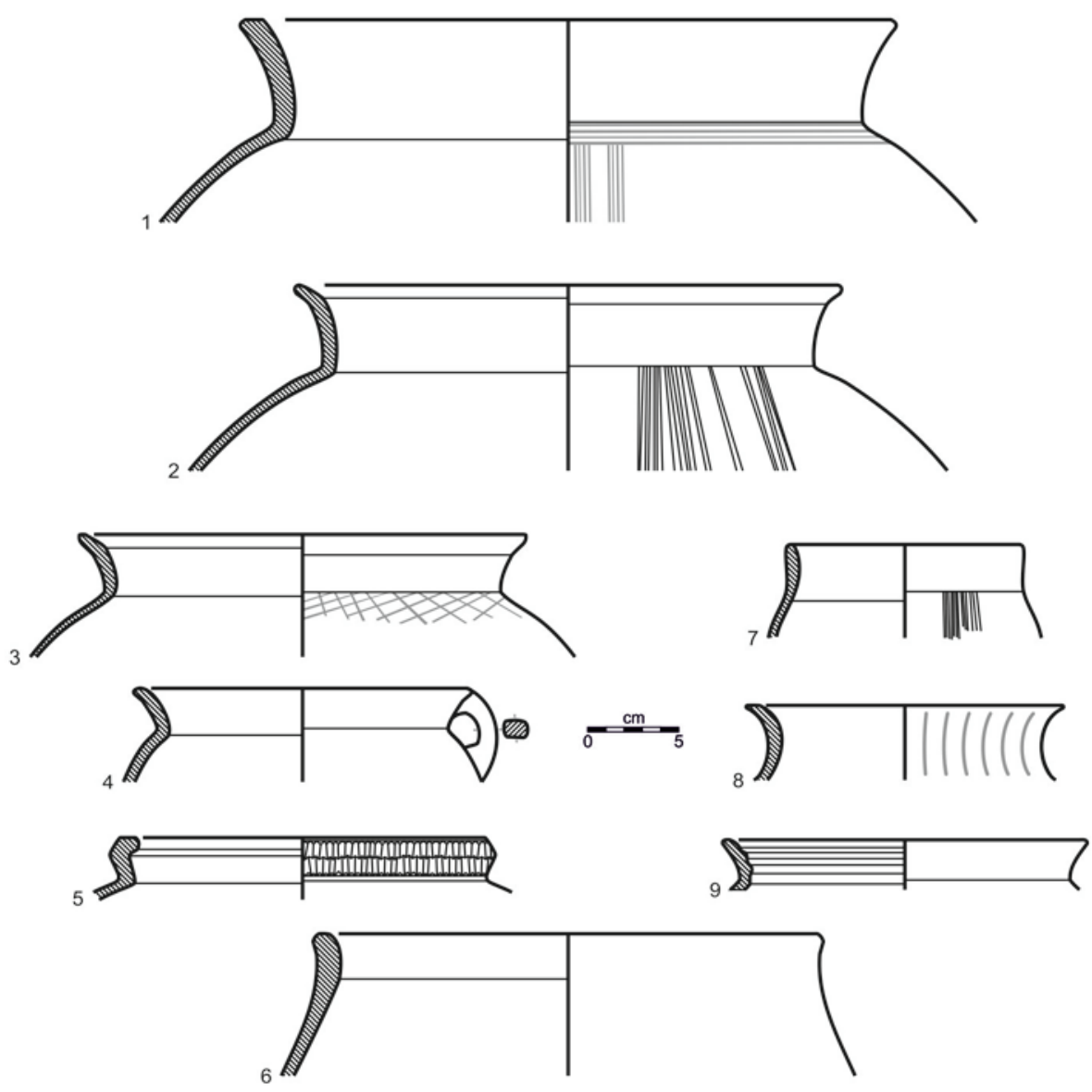

Fig. 12. Cerámica nativa de la zona este del sistema defensivo. Ollas (1-9). 
Respecto a los cuencos, representados en menor medida, predominan las formas con un borde con desplazamiento horizontal cerrado acabado en labio redondeado o plano y cuerpo convexo o convexo oblicuo abierto (Fig. 13, 1-5), a excepción de una pieza con borde con desplazamiento horizontal bilateral (Fig. 13, 6). Sus dimensiones van de los 27 a los $42 \mathrm{~cm}$ de diámetro de borde. Muchos de estos cuencos presentan una decoración a base de líneas incisas en la parte superior del labio (Fig. 13, 3).
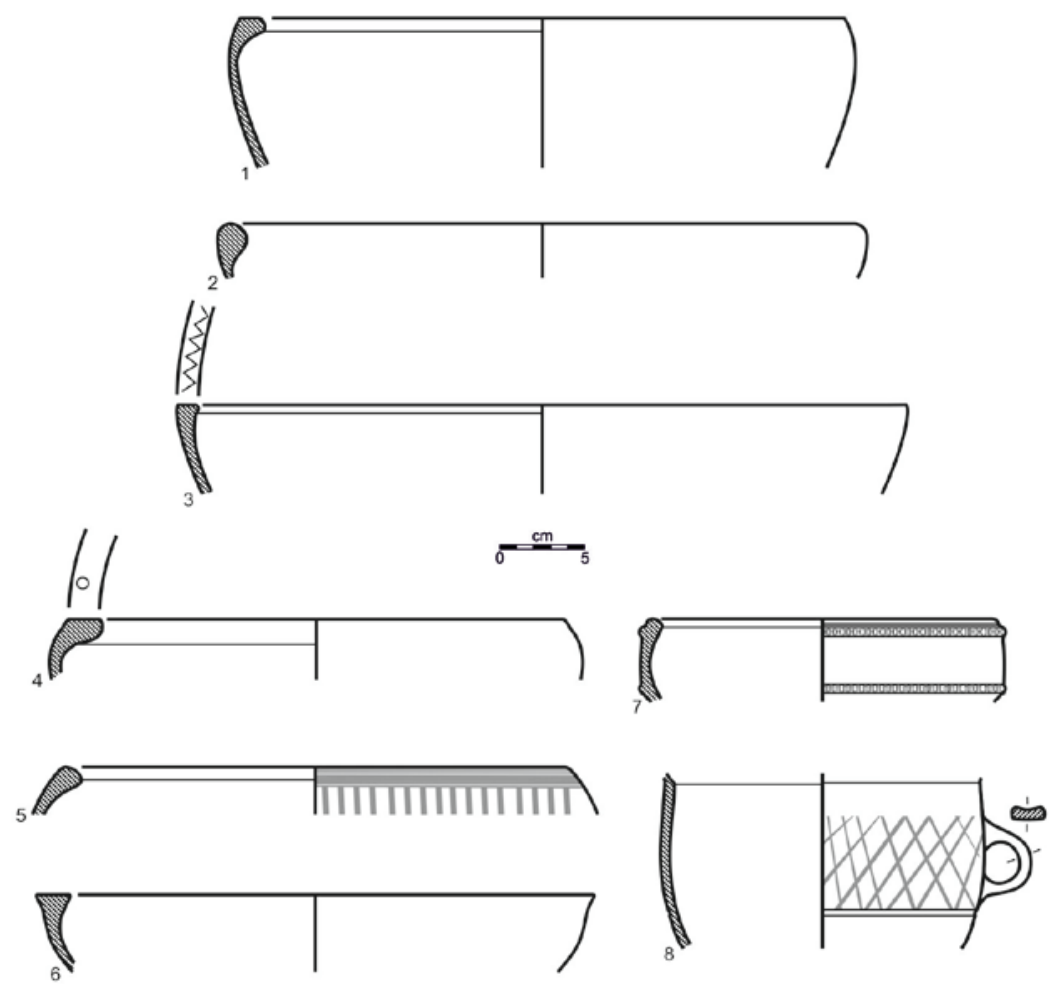

Fig. 13. Cerámica nativa de la zona este del sistema defensivo. Cuencos (1-7) y vaso (8).

Resaltamos una pieza (Fig. 13, 7) con labio plano y cuerpo convexo que muestra dos cordones plásticos horizontales con líneas incisas oblicuas, otra (Fig.13, 5) con decoración bruñida de líneas horizontales y verticales en la cara externa del cuerpo, y una última pieza (Fig. 13, 4), que tiene un pequeño orificio vertical en el borde. 
En esta zona también documentamos un vaso o tazón con decoración, tipo L16 (Fig. 13, 8), caracterizado un pequeño borde oblicuo con un diámetro de 18 cm y cuerpo convexo con un asa de sección rectangular, así como una decoración en base a líneas bruñidas oblicuas que conforman un motivo reticulado en la cara externa del cuerpo, situada sobre una línea espatulada horizontal.

\section{3. Zona sudeste del recinto central (1996)}

Acudimos a otras zonas del castro para ampliar la información y poder contrastarla. Para ello estudiamos los restos cerámicos recuperados durante la campaña realizada en 1996 por la empresa de arqueología Terra Arqueos. Excavaron una zona próxima a la entrada principal situada al sudeste del recinto central, no excavada anteriormente (Fig. 14), y realizaron una ampliación en la zona de expansión situada al oeste del castro, ya excavada en los años 70 y en 1992.

Tras retirar los niveles superficiales, se identificaron “...dúas rúas o zonas de paso [...] en torno a elas algunhas estructuras de habitación pertencentes a distintos barrios" (López González et alii, 1996: 67). Entre estas "calles” se encuentra el denominado como "barrio II", en el que se documentó: "unha estructura principal que é rectangular e que na zona onde confluen as rúas ten un reforzo semicircular.” (López González et alii, 1996: 67). En dirección norte se excavó parte de “... unha construcción rectangular escavada de antergo e que ten sobrepasado o nivel de solo...” (López González et alii, 1996: 68). Sin embargo, la construcción más relevante es la del "barrio I":

“...unha construcción circular cunha pequena dependencia adosada, semicircular, sita na zona de acceso a vivienda" en cuyo interior se documentó un "fogar enmarcado por lousas fincadas en vertical e ten adosado un pequeno poiete ou banco de pedra. Sobre o chan na zona sur documentouse outro banco de pedra, mentras que o leste afloraba ó rocha o nivel do pavimento.” (López González et alii, 1996: 68).

A nivel estratigráfico, la documentación indica que los espacios asociados os exteriores de las estructuras tienen un solo nivel en la estratigrafía vertical mientras que los interiores de las viviendas o habitaciones tienen un nivel de derrumbe y otro de ocupación (López González et alii, 1996: 48). Los excavadores concluyen que esta zona sudeste tiene las mismas características que el resto del recinto central, coincidiendo con “...a cronoloxía que ten o xacemento fruto das investigacións nas anteriores campañas de escavacións realizadas.” (López González et alii, 1996: 49). 


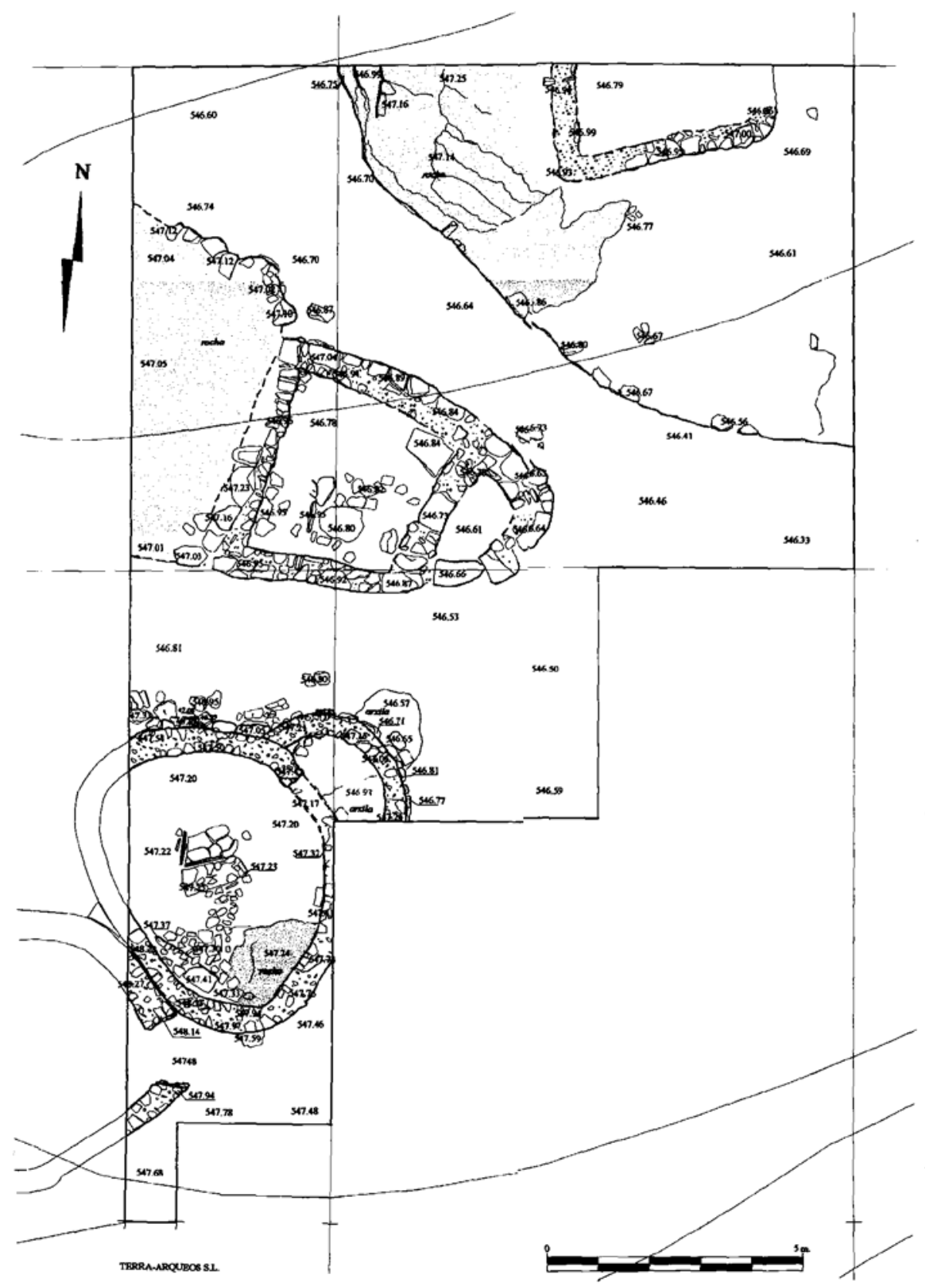

Fig. 14. Plano de la zona sudeste del recinto central (López González et alii, 1996). 


\section{3. 1. Cerámica nativa de la zona sudeste del recinto central}

En esta zona, a diferencia de las anteriores, la cerámica nativa no es la producción más abundante si tenemos en cuenta la totalidad de los restos cerámicos recogidos. Las ollas, que se documentan en mucha menor medida si comparamos esta zona con las anteriores, encajan dentro de los grupos descritos anteriormente, concretamente con el segundo grupo formal (Fig. 15, 1-4) de labio redondeado seguido por un borde con desplazamiento horizontal abierto o un borde oblicuo que, a través de un cuello cóncavo oblicuo cerrado, se une a un cuerpo convexo. Estas ollas tienen unos diámetros de borde de tamaño medio y grande, entre los 23 y los $38 \mathrm{~cm}$.

Hay que diferenciar una ollita (Fig. 15, 7) de $11 \mathrm{~cm}$ de diámetro de borde, tiene un borde casi recto seguido por un cuerpo convexo, y presenta un asa de sección circular situada en la parte media del cuerpo.

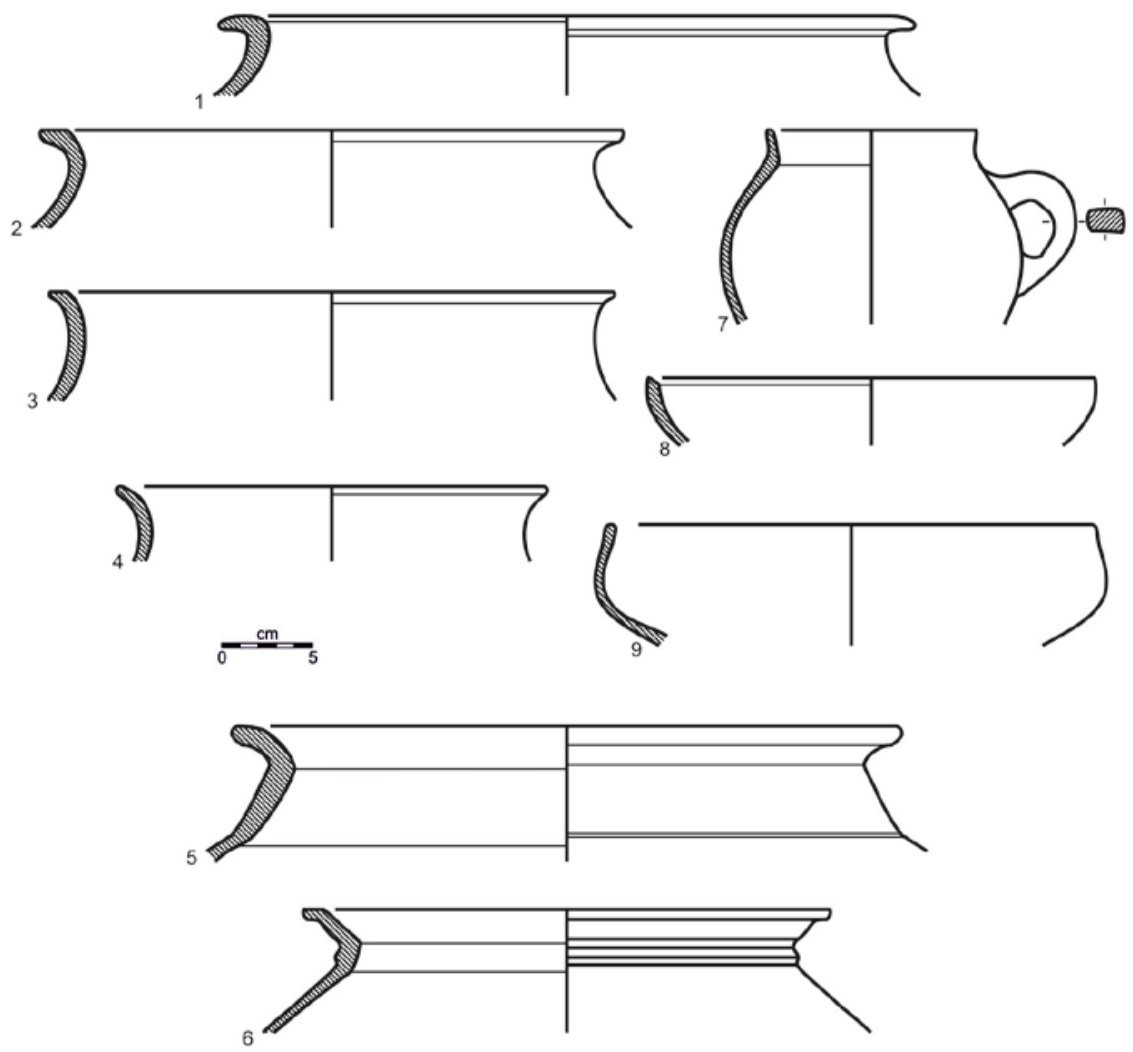

Fig. 15. Cerámica nativa de la zona sudeste. Ollas (1-7) y cuencos (8-9). 
En esta zona también se documenta el mismo subgrupo que en otras zonas, que difiere en forma y tecnología respecto al conjunto de la cerámica nativa. Por un lado, identificamos las ollas de borde facetado, caracterizadas por un borde con desplazamiento horizontal abierto, cuello oblicuo y cuerpo convexo, o con borde oblicuo, sin cuello y cuerpo convexo (Fig. 15, 5-6). Estas piezas tienen unas dimensiones que van entre los 18 y los $37 \mathrm{~cm}$ de diámetro de borde.

Dentro de este subgrupo hemos identificado un pequeño conjunto de cuencos en el que agrupamos varias piezas que presentan un labio redondeado, muy ligeramente engrosado hacia el interior, seguidos por un cuerpo convexo poco desarrollado con una leve carena en su parte media (Fig. 15, 9). Con un diámetro de borde entre los 21 y los $27 \mathrm{~cm}$, recuerdan vagamente a los L12 de Lugo (Alcorta, 2001: 111-113, fig. 49), especialmente a nivel tecnológico, sin embargo, las diferencias morfológicas nos impiden incluirlos dentro de este tipo.

Resaltamos una pieza (Fig. 15, 8) que, aunque está incluida dentro del conjunto de los cuencos, tiene una morfología diferente al resto, con un labio plano ligeramente ranurado y un cuerpo convexo, su diámetro de borde es de 24 cm y no descartamos que pueda tratarse de una tapadera, dada su morfología.

\section{3. 2. Cerámica común romana de la zona sudeste del recinto central}

En esta zona las producciones romanas se documentan en mayor medida que las nativas. El grupo de las ollas también sobresale ligeramente respecto a otras zonas. Con unas dimensiones que van de 12 a $29 \mathrm{~cm}$ de diámetro de borde, identificamos aquí los tipos O1 y O2 (Fig. 16, 1), O24 (Fig. 16, 4) y O7 (Fig. 16, 2-3), también relacionadas con las ollas CNT-AQTA.

Así mismo, se han identificado un pequeño conjunto de lo que parecen jarras (Fig. 16, 5-8) de pequeñas dimensiones, con diámetros de borde de entre 7 y $13 \mathrm{~cm}$. Una de las piezas presenta un borde oblicuo acabado en labio redondeado cuello convexo y asa de sección ovalada que parte del cuello. El escaso desarrollo de su perfil y su mala conservación impide adscribirla a un tipo concreto (Fig. 16, 5).

Tenemos varias piezas de similares características, pero con un borde más grande, de 11,5 cm de diámetro (Fig.16, 6), que podrían encuadrarse dentro del tipo J7 (Alcorta, 2001: 293-294, fig. 123) pero de nuevo su reducido desarrollo no permite asegurarlo.

También se ha analizado una pieza de borde recto seguido de un cuello cóncavo (fig.16, 8) en el que parece apreciarse restos de engobe en su cara externa, lo que podría identificarla como una EJ1 (Alcorta, 2001: 295-296, fig. 124) pero su reducido tamaño no aconseja adscribirla a ningún tipo concreto. 
Todas estas piezas se caracterizan por unas pastas color siena o naranja claro con abundantes desgrasantes en superficie, y carecen de decoración.

Por otro lado, hemos analizado un recipiente de borde oblicuo convexo, con un perfil poco desarrollado y terminado en un labio redondeado, seguido de un cuello ligeramente cóncavo y alargado (Fig. 16, 7). Presenta pastas grises con pocos desgrasantes $\mathrm{y}$ un correcto tratamiento superficial. Por sus características, puede encuadrarse dentro de las J1, aunque sin decoración, pero debido a la falta de desarrollo del perfil de la pieza, no podemos afirmarlo.
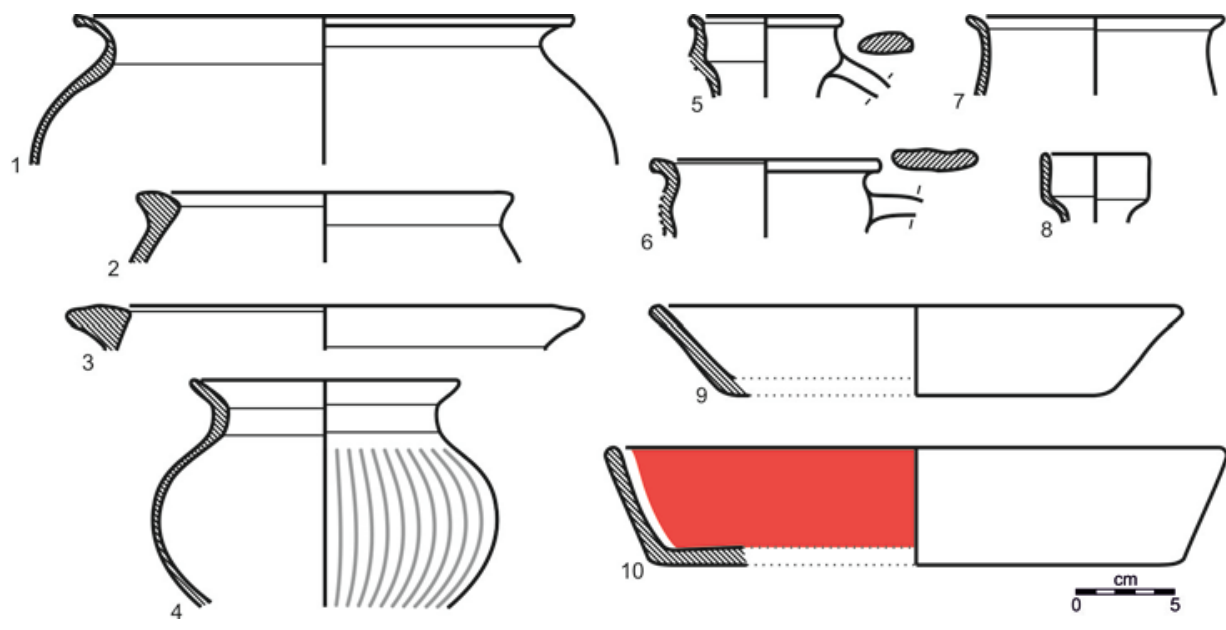

Fig. 16. Cerámica común romana de la zona sudeste. Ollas (1-4), jarras (5-8) y platos (9-10).

Documentamos un grupo de platos (Fig. 16, 9-10) con una apertura de borde de entre 24 y $30 \mathrm{~cm}$. Uno de ellos es un tipo P1 (Fig. 16, 9) y el resto (Fig. 16, 10) coincidien con los EP1, engobados, de Lugo, (Alcorta, 2001: 344346, fig.144).

Dentro de las fuentes, analizamos una pieza de perfil completo (Fig. 17, 4). Tiene un labio engrosado y un cuerpo oblicuo abierto que acaba en una base plana de $36 \mathrm{~cm}$ de diámetro; esta forma se puede relacionar con algunos de los platos documentados en Lugo por sus características tecnológicas, con unas pastas de color siena oscuro, abundantes desgrasantes y alisado superficial, aunque no encaja a la perfección en ningún tipo debido a su morfología. Además, hemos identificado varias fuentes tipo EP6 (Fig. 17, 5), engobadas, con un diámetro de borde de entre 23 y $31 \mathrm{~cm}$. Por último, contamos con la 
presencia de dos ejemplos de cerámica gris tardía, una fuente con borde con desplazamiento horizontal abierto de 35,6 cm de diámetro (Fig. 17, 7) tipo GT1 (Alcorta, 2001: 383-386, fig. 162), y una fuente de borde engrosado de sección triangular con 19,4 cm de diámetro de borde (Fig. 17, 6), tipo GT3 (Alcorta, 2001: 386-387, fig. 163).

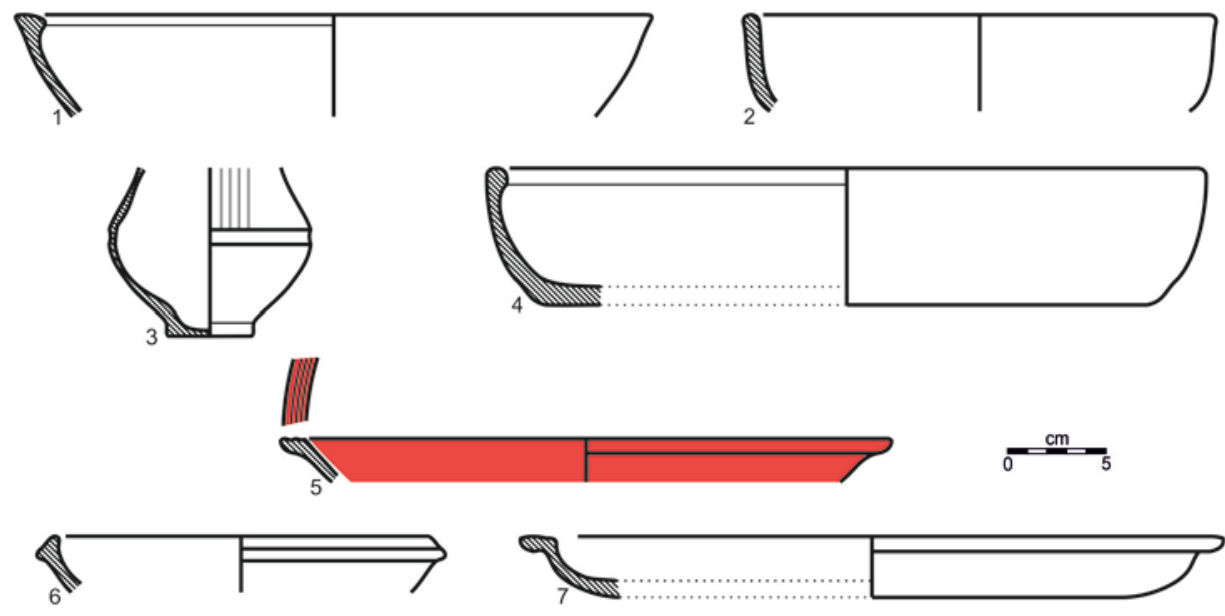

Fig. 17. Cerámica común romana de la zona sudeste. Cuencos (1-2), vaso (3) y fuentes (4-7).

También documentamos un conjunto de piezas tipo V2 (Fig. 17, 3) con unas dimensiones de entre 7 y $9 \mathrm{~cm}$ de diámetro de borde, y un grupo de cuencos que dividimos en dos: por un lado, los C3 (Fig. 17, 1), con unos diámetros de borde de entre 21 y $39 \mathrm{~cm}$ y por otro lado, un cuenco de $24 \mathrm{~cm}$ de diámetro de borde, con un labio redondeado y ligeramente engrosado hacia el exterior, seguido de un cuerpo convexo oblicuo abierto marcado en la parte inferior por una carena o leve inflexión (Fig. 17, 2) que, por sus características tecnológicas, podría coincidir con los C3, pero que difiere en su forma.

\section{4. Zona de expansión oeste (1996)}

En la zona de expansión oeste, excavada también en 1996 por Terra Arqueos, se amplió el trazado del camino conocido (Fig. 18) y al sur se documentó “... parte dunha estructura de habitación cun espacio exterior sito o leste o borde do muro que delimitaba o acceso” (López González et alii, 1996: 69). Este espacio estaba pavimentado con losas de pizarra y los excavadores le 
presuponen un uso como zona de trabajo y almacenaje adosado a la vivienda ya que aquí se documentaron restos de semillas (López González et alii, 1996: 69). En el interior se encontraron dos pequeñas estructuras: un "contedor de forma rectangular, feito con lousas de pedra e delimitado cuns pequenos muretes" y "un silo de forma circular escavado chan” (López González et alii, 1996: 69). Para esta zona se plantea la pregunta de si su ocupación fue simultánea a la del recinto central o si, por el contrario, fue una expansión de la población en un momento concreto de la ocupación del castro (López González et alii, 1996: 49).

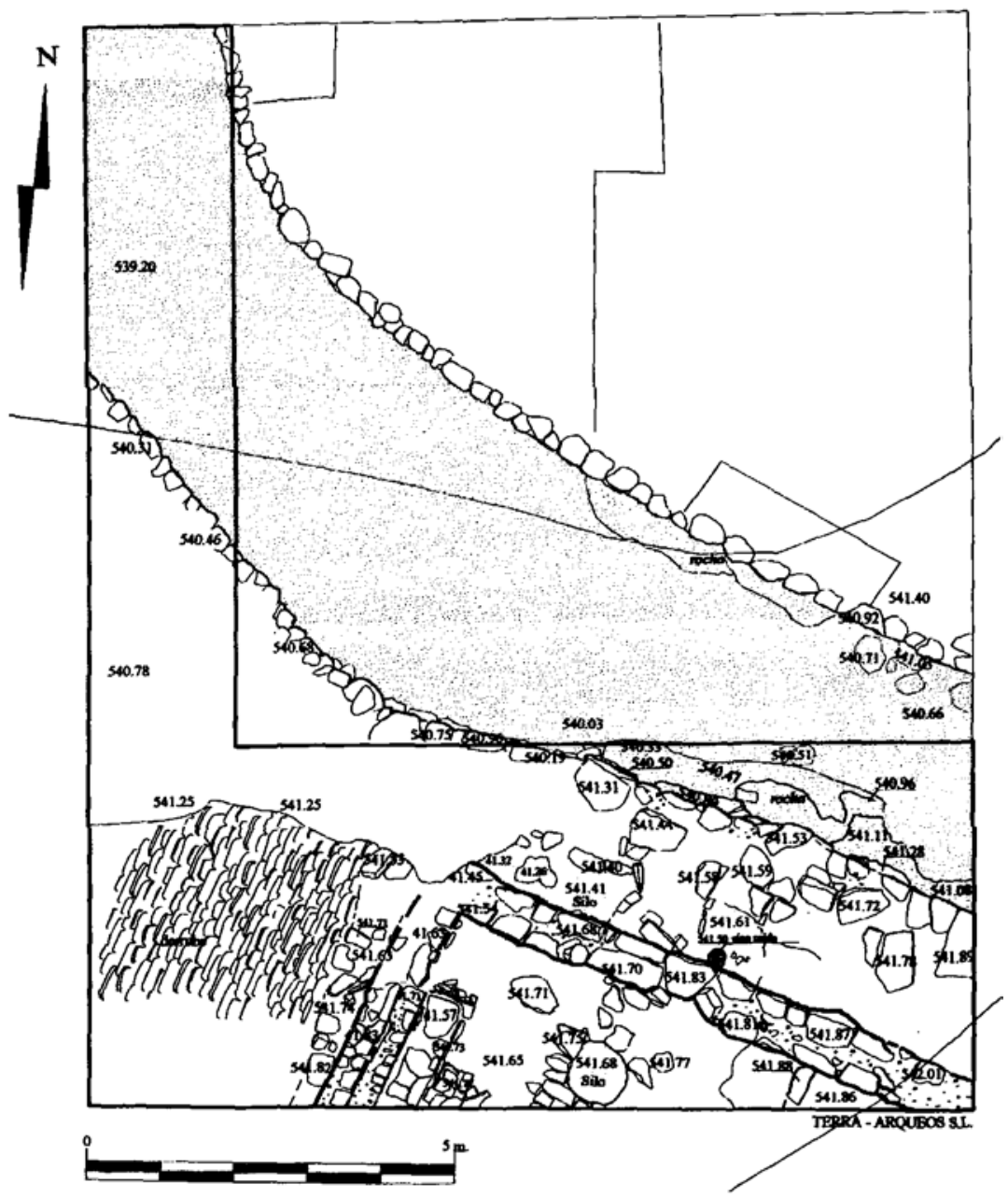

Fig. 18. Plano de la zona de expansión (López González et alii, 1996). 
Durante la campaña de excavación se realizaron varias dataciones radiocarbónicas sobre dos muestras de madera, una (CSIS n ${ }^{\circ} 1321$ ) recogida en el exterior de la vivienda, "metida por baixo o muro de peche e, polo tanto, anterior a ese muro" (López González et alii, 1996: 50) y otra (CSIS n 1220) en el camino de acceso, "ó pe do muro que delimitaba a rúa, nun nivel mixturado con algún restos de derrube do muro, polo que pertence a un momento de abandono do camiño" (López González et alii, 1996: 50). Los resultados de este análisis dan fechas opuestas, la primera muestra, tomada en el exterior de la vivienda, da una fecha de entre el s. III y el I a.C., y la segunda, recogida en el camino, da una datación estimada entre el s IV-VI d.C. (Fig. 11).

En esta zona prácticamente solo se ha documentado cerámica común romana, a excepción de un pequeño conjunto cuya mala conservación desaconseja realizar sobre él grandes inferencias. Se trata de cuatro fragmentos de ollas caracterizadas por un borde con desplazamiento horizontal abierto, cuello oblicuo y cuerpo convexo, o con borde oblicuo, sin cuello y cuerpo convexo. Estas piezas tienen unas dimensiones que varían entre los 18 y los 25 cm de diámetro de borde. Podrían tratarse de ollas de borde facetado, aunque el escaso desarrollo del perfil de estas cerámicas no ha permitido adscribirlas con seguridad a ningún tipo. Por sus características tecnológicas, se trata de cerámica nativa (Fig. 19, 6-8).
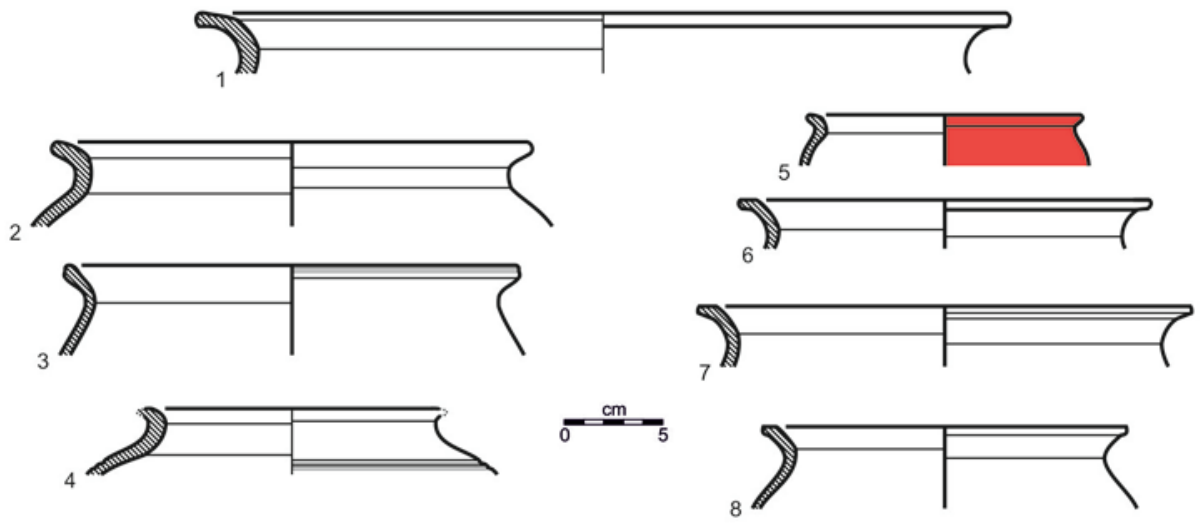

Fig. 19. Cerámica común romana (1-5) y nativa (6-8) de la zona de expansión. Ollas. 


\section{4. 1. Cerámica común romana de la zona de expansión oeste}

Las ollas, con unas dimensiones que van de 14 a $34 \mathrm{~cm}$ de diámetro de borde, se adscriben a los tipos O1 (Fig. 19, 3), O2 (Fig. 19, 2) y O5 (Fig. 19, 4) de Lugo (Alcorta, 2001:202-204, fig. 85). Carecen de decoración a excepción de algunas acanaladuras horizontales bajo el borde en el caso de la O5 (Fig. 19, 4).

Resaltamos un borde de grandes dimensiones, $41 \mathrm{~cm}$ de diámetro, que podría corresponderse con la O12 de Lugo (Fig. 19, 1), pero cuyo reducido tamaño no permite afirmarlo, y otra pieza con un borde y cuerpo que, morfológicamente coincide con las O24 (Fig. 19, 5), pero difiere en pastas y tratamiento superficial, presentando una tonalidad naranja y un engobe en la cara externa del cuerpo.

Se ha identificado un grupo de jarras con diámetros de apertura de borde de entre 3 y $17 \mathrm{~cm}$. Dentro del mismo, se ha documentado un recipiente tipo J1, aunque sin decoración (Fig. 20,3).

Además, hemos identificado una pieza de borde y cuello de una jarra tipo EJ2 (Alcorta, 2001:297-298, fig. 125), engobada (Fig. 20, 2) y otro de tipo EJ1 (Fig. 20,1) también engobada.

Por último, tenemos un pequeño conjunto caracterizado por un diámetro mayor que el resto, de entre 13 y $17 \mathrm{~cm}$ y una morfología que presenta un borde oblicuo, en ocasiones con moldura, seguido de un cuello cóncavo (Fig. 20, 4). Estas piezas se podrían clasificar como J7, o cántaros biansados, pero el exiguo desarrollo del perfil hace imposible precisarlo. Tienen pastas ocres y anaranjadas, y presentan abundantes desgrasantes en la superficie.

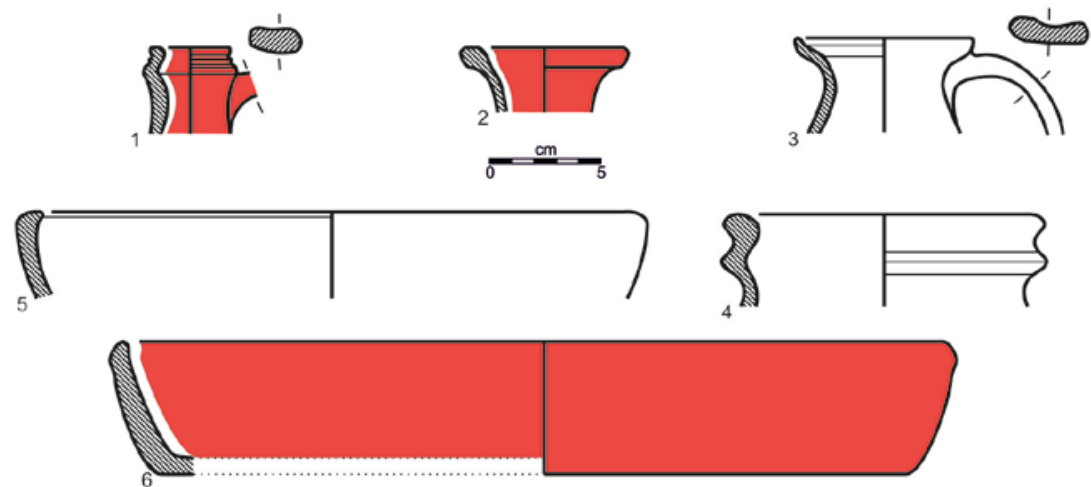

Fig. 20. Cerámica común romana de la zona de expansión. Jarras (1-4) y platos (5-6). 
Otro grupo que analizamos, aunque en menor medida, es el de los platos (Fig. 20, 5-6). Con una apertura de borde de entre 28 y $37 \mathrm{~cm}$, los dividimos en el tipo P1 (Fig. 20, 5) y EP1 de Lugo (Fig. 20, 6).

\section{5. Zona sudoeste del recinto central (2016)}

Para finalizar la segunda parte de este estudio se analizaron las colecciones cerámicas procedentes de la campaña de 2016, una de las últimas realizadas en este asentamiento. Este año se excavó una nueva zona de $39 \mathrm{~m}^{2}$ (Fig. 21) en el tramo sudoeste de la "calle" principal del recinto central (López González et alii, 2017). En esta excavación se pudo identificar los límites de la "calle", delimitada al sur por "....un corte na roca e por unha pequena cimentación duhna estrutura circular case perdida, e ó norte por un pequeno muro de contención.” (López González et alii, 2017: 22). Posteriormente se realizó una ampliación en esta actuación hacia el este y el oeste para tener una zona de paso recuperada en su totalidad, ocupando finalmente la intervención una superficie de unos $120 \mathrm{~m}^{2}$ (López González et alii, 2016: 15). En este espacio se localizan la mayor parte de los materiales registrados en esta campaña, incluido un "conxunto de pequenas moedas de época tardía, procedente do derrumbe da construción aledaña polo sur que se atopa caído sobre este espazo" (López González et alii, 2016: 238). Según el análisis estratigráfico se documentó la existencia de "un nivel de uso ou frecuentación cos restos da última fase de ocupación” (López González et alii, 2016: 225), que os excavadores sitúan dentro de "unha época xeral en torno ao século IV d.C." (López González et alii, 2016: 238).

\section{5. 1. Cerámica común romana de la zona sudoeste del recinto central}

Estas producciones son las únicas que hemos podido observar en esta zona. Analizamos un grupo de ollas y ollitas con unas dimensiones que van de 12 a 28 cm de diámetro de borde y que se corresponden con los tipos O1 (Fig. 22, 3) O2 (Fig. 22, 4), O7 (Fig. 22, 1-2) y O24 (Fig. 22, 5) Carecen de decoración, a excepción de algunas molduras horizontales bajo el borde y líneas bruñidas verticales en la cara externa del cuerpo en el caso de algunas ollitas tipo O24 (Fig. 22, 5) y un marcado cepillado en la cara externa del cuerpo en una de las O7 (Fig. 22, 2), lo que contribuye a relacionarlas con las CNT-AQTA.

Dentro del grupo de los platos, diferenciamos dos tipos, los P1 (Fig. 22, 7) y el tipo EP1 (Fig. 22, 8), con una apertura de borde de entre 21 y $30 \mathrm{~cm}$.

Hay que mencionar dos fuentes de borde con desplazamiento horizontal abierto. La primera sería una cerámica gris tardía tipo GT1 (fig. 22, 9), tiene 26 
cm de diámetro de borde y presenta una decoración bruñida en la cara superior del borde, formando un motivo zigzagueante.

La segunda es una imitación de la Hayes 59 (Fig. 22, 10), tipo I59 de Lugo (Alcorta, 2001: 375-382, fig. 158-161), caracterizada por unas pastas ocres y un fondo plano con acanaladuras concéntricas a modo de decoración, su diámetro de borde es de $41 \mathrm{~cm}$, y presenta un engobe en la cara interna del cuerpo.

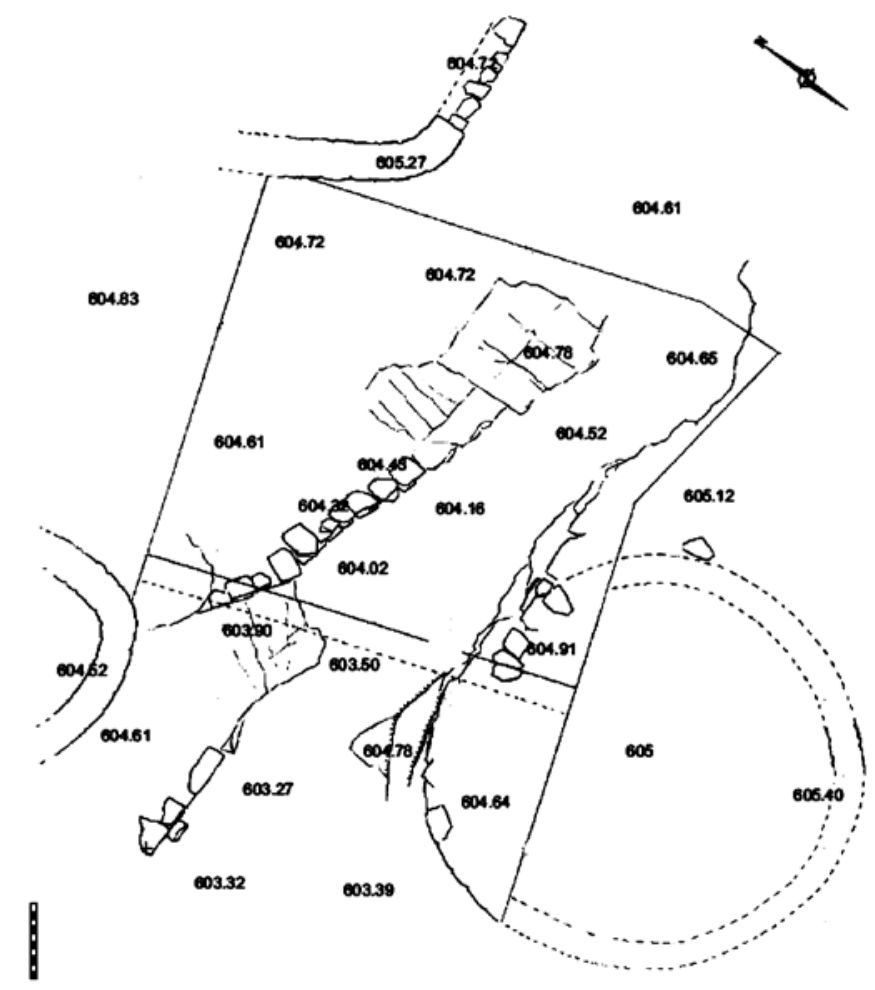

Fig. 21. Plano de la zona sudoeste (López González et alii, 2016).

Uno de los tipos que documentamos más residualmente es el de los vasos tipo V2 (Fig. 22, 6), con unas dimensiones de entre 9 y $14 \mathrm{~cm}$ de diámetro, de borde oblicuo y cuello cóncavo seguido de un cuerpo convexo sin apenas inflexión. Estos vasos presentan decoración en la cara externa del cuello a través de bruñidos verticales. 

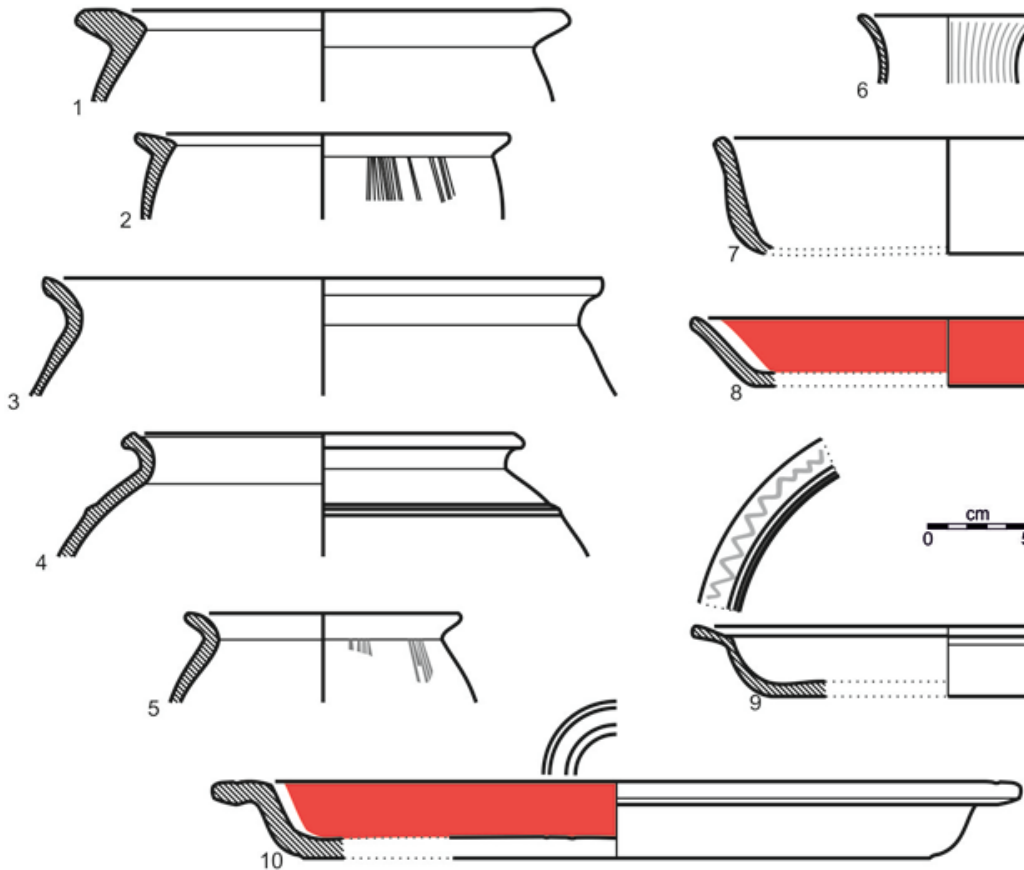
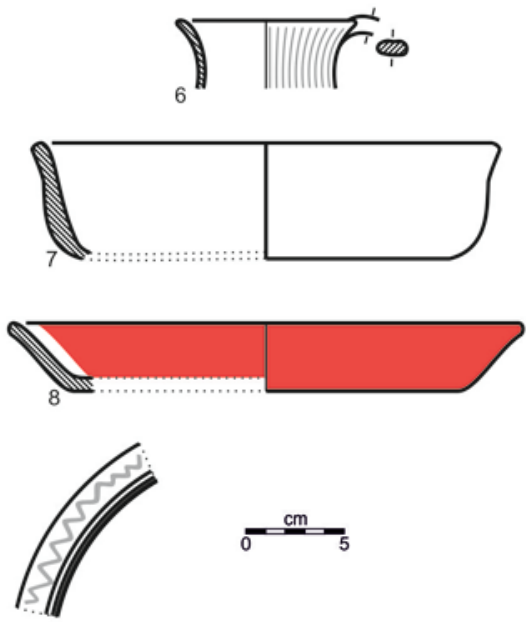

Fig. 22. Cerámica común romana de la zona sudoeste. Ollas (1-5), vaso (6), platos (7-8) y fuentes (9-10).

Hay que mencionar la presencia de un mortero (Fig. 23, 4) de borde con desplazamiento horizontal abierto y pico vertedor, Su diámetro de apertura de borde es de $40 \mathrm{~cm}$. De factura tosca, sus pastas son de color ocre y presenta abundantes desgrasantes micáceos y cuarcíticos. Su estado de conservación es deficiente y no permite observar su tratamiento superficial.

Además, se ha analizado una tapadera de base plana y asa central de sección oval, caracterizada por presentar una decoración incisa ondulante bordeando la cara externa (Fig. 23, 3), para la que no tenemos un paralelo significativo.

Resaltamos dos piezas que, por sus características morfotecnológicas, podrían ser consideradas como imitaciones de otras producciones. Por un lado, un cuenco de $25 \mathrm{~cm}$ de diámetro de borde, borde oblicuo y cuerpo convexo (Fig. 23, 2), pastas color siena oscuro y cuidado alisado, que podría tratarse de una imitación de una Drag. 27. (Alcorta Irastorza, E. 2001: 367-368) muy similar a la identificada en el noreste del recinto (Fig. 9, 1). Sin embargo, la presencia de unos orificios en la parte central del cuerpo difiere del tipo y 
sugiere que pudo tener otra función. Por otro lado, un recipiente prácticamente completo de borde con desplazamiento horizontal abierto, cuerpo recto y pie realzado (Fig. 23, 1), que se asemeja a la forma Rigoir 7 (Rigoir, 1968: 223), de la TSGT o DSP, aunque con pastas naranjas y engobe en ambas caras del cuerpo.
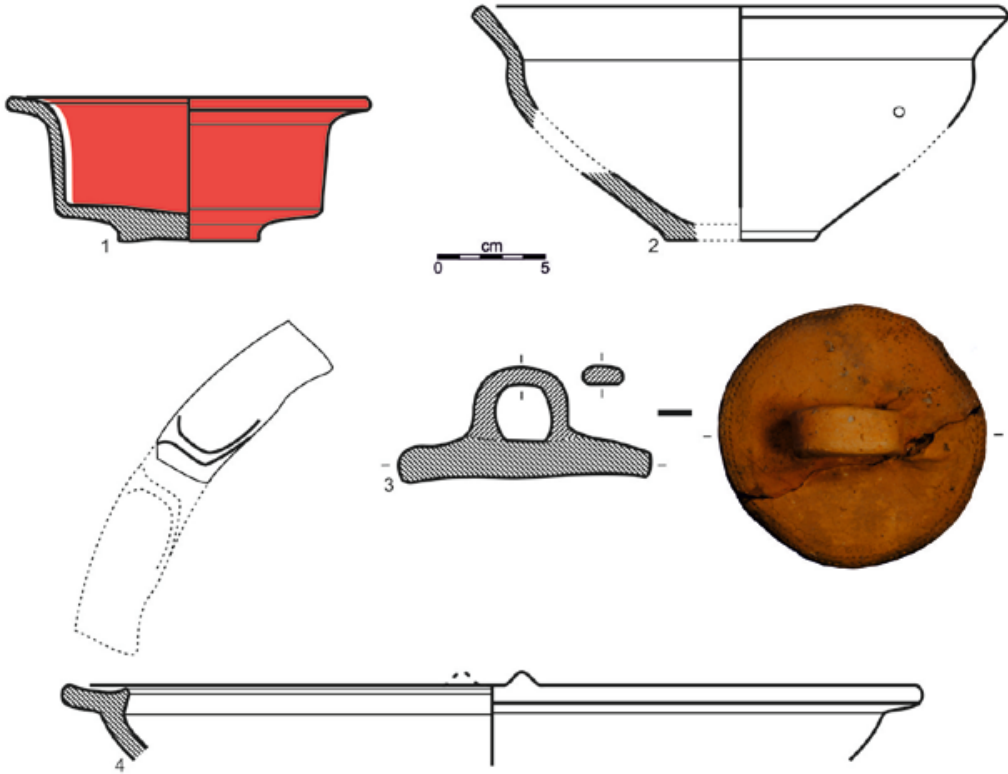

Fig. 23. Cerámica común romana de la zona sudoeste. Mortero (4), tapadera (3) y otros (1-2).

\section{CONSIDERACIONES CRONOLÓGICAS EN LAS ZONAS ANALIZADAS: MATERIALES Y ESTRATIGRAFÍA}

\section{1. Zona noreste del recinto central (Años 70, 1983, 1984 y 1992)}

Analizando cada zona en su conjunto, en la zona noreste del recinto central la cerámica nativa es más abundante que la cerámica común romana, proliferando las ollas de borde recto u oblicuo y cuerpo convexo, seguidas en mucha menor medida por los cuencos de borde con desplazamiento horizontal cerrado y cuerpo convexo. Aunque son piezas con características tecnológicas muy similares, identificamos algunos tipos que, siendo considerados nativos, muestran una morfotecnología algo diferente, como las ollas de borde facetado, 
el vaso L16 y las tazas monoansadas. La cerámica común romana de esta zona muestra una mayor variabilidad formal respecto a la nativa, documentándose ollas, jarras, cuencos, platos y fuentes, sin que predomine ninguna forma sobre las demás.

Respecto a lo que estas producciones pueden aportar acerca de la cronología de esta zona, la cerámica nativa estudiada presenta unas características morfotecnológicas similares a las de las cerámicas documentadas en castros de época romana, como Punta do Castro (Lozano et alii, 2015), el castro de Zoñán (Vigo García, 2007) o el castro del Chao Samartín (Hevia et alii, 2009), diferenciándose en sus características tecnológicas de cerámicas nativas más antiguas documentadas en sitios como el Castro de Vixil (Ramil Rego, 1997), no mostrando, salvo algunas excepciones, la característica decoración plástica en el cuerpo. Hay ciertos tipos que actualmente pueden acotar algo más esta cronología, como las ollas de borde facetado, presentes en el Chao Samartín en los s. I y II d.C. (Hevia et alii, 2009: 88), o los vasos L13 y L16 de Lugo (Alcorta, 2001: 114 y 124), con una cronología que va del s. I al II d.C. (Fig. 24).

Dentro de la cerámica común romana, en esta zona se documentan tipos de larga adscripción cronológica, como las ollas tipo $\mathrm{O} 1$ y O2, situadas entre el s. II y el V (Alcorta, 2001: 196-197), junto con platos P1 y EP3 de cronología similar (Alcorta, 2001: 348 y 359). Los vasos tipo V2 estarán presentes a partir del s. II en Lugo, hasta finales del S.IV (Alcorta, 2001: 267). Con cronologías algo más precisas tenemos los cuencos tipo C3, situados entre el s. I y II (Alcorta, 2001: 332), las ollas O24, entre el s. II y el IV (Alcorta, 2001: 252), las jarras J1, de mediados del s. II hasta mediados del s. IV d.C. (Alcorta, 2001: 280), o el cuenco de imitación I27, a grandes rasgos situado en el s. III d.C. (Alcorta, 2001: 368) Asimismo, hay que subrayar algunas piezas de marcado carácter tardío, como las fuentes tipo EP6 y las ollas O7, que van del s. IV al V (Alcorta, 2001: 354 y 208), y el cuenco que se asemeja a las formas de TSGT, cuya producción atlántica está situada entre el s. IV y el VI d.C. (Uscatescu et alii, 1994: 288). Con lo cual esta producción marca un arco cronológico bastante amplio para el noreste del recinto central (Fig. 24).

Si contrastamos esta información con los distintos niveles que se describen para esta área (Arias Vilas et alii, 2016: 23), veremos que, en ninguna de las campañas arqueológicas llevadas a cabo en esta zona del castro, se ha contado con un registro estratigráfico que vaya más allá de la numeración de las cuadrículas y de los materiales registrados en ellas. No se han reflejado en ningún lugar las coordenadas o la profundidad a la que se recuperaban las piezas ni tampoco su posible contexto.

Sin embargo, debemos tener en cuenta que la mayor parte de la cerámica común romana aparece en las campañas de los años 70 y de 1983, por lo que 
suponemos que se excavaron los niveles superiores; mientras que en las campañas de 1984 y 1992 es probable que se profundizase más pues fue entonces cuando se documentó la mayor potencia estratigráfica y los supuestos niveles prerromanos. En este momento la cerámica romana se constata de manera muy marginal, encontrándose solo tres piezas, junto con un dudoso fragmento de tégula.

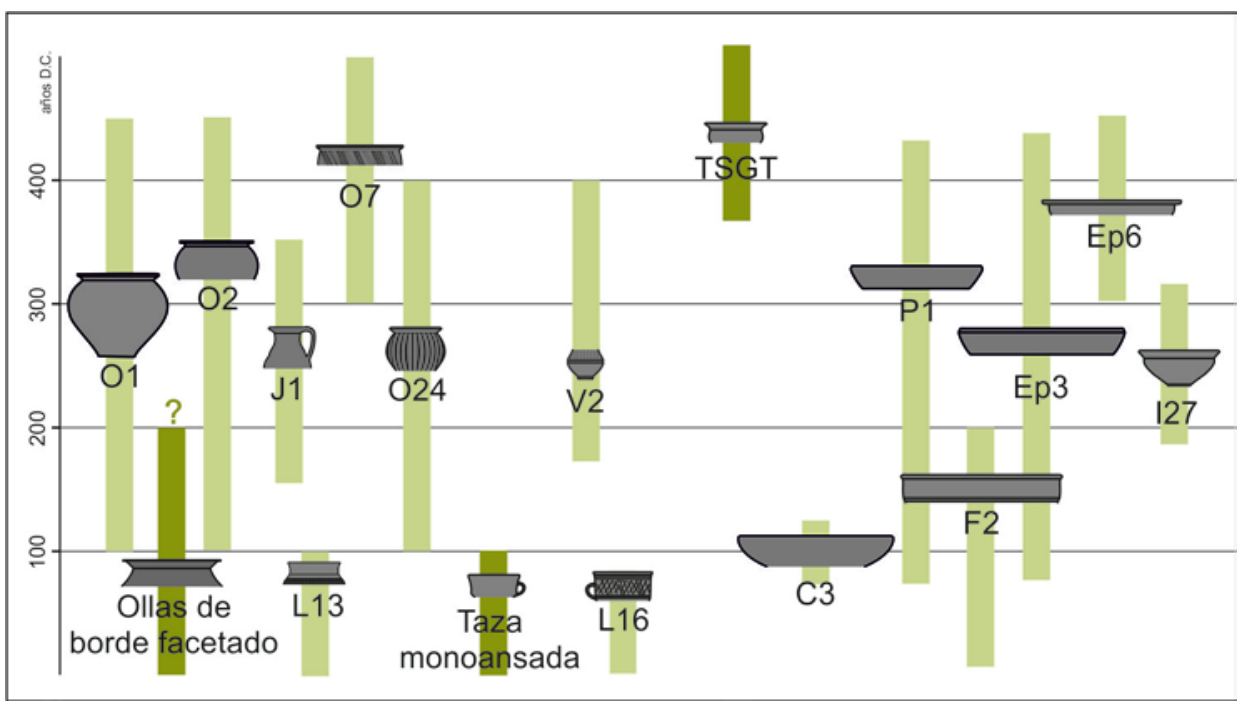

Fig. 24. Cuadro cronológico de la zona noreste según los datos de Alcorta (2001), Hevia et alii (2009) y Rigoir (1968).

Respecto a la aportación de otros materiales acerca de la cronología de esta zona, hay que aclarar que la mayoría de la terra sigillata y de las monedas encontradas en los años 70 no cuentan con una referencia que indique la zona exacta de su procedencia dentro del yacimiento, por lo que pueden existir muchas piezas procedentes de esta zona de las que no tenemos constancia. Consultando las fichas del museo y ciñéndonos a aquellas piezas de las que sí sabemos su procedencia, hemos documentado en las campañas de los años 70 una pieza de TSH, fechada entre el s. II y el III y nueve piezas relacionadas con la TSHT con cronologías entre el s. III y el V, junto con una Drag.37, fechada entre el s. IV y V. Las monedas con procedencia conocida pertenecen a la campaña de 1983, y son 9 follis situados entre el s. III y el V d.C. y 4 semis del s. IV y V d.C. La cronología de las monedas y de la terra sigillata, de carácter impreciso, se ha extraído de las fichas del Museo de Viladonga. 
Así pues, en los niveles de los años 70 y de 1983, considerados más recientes, se documentan materiales que van del s. I al V d.C. con tipos altoimperiales, tipos más tardíos y monedas bajoimperiales. En los niveles de 1984 y 1992, considerados más antiguos, la falta de cerámica común romana podría hacer suponer que son previos a la conquista, sin embargo, hemos de tener en cuenta varios factores: por un lado, los supuestos niveles prerromanos no tienen ninguna estructura definida asociada a los materiales, más allá de los “dous pequenos muros desfeitos” (Arias Vilas, 2000: 193) que se exhumaron en la excavación de 1992. Por otro lado, las producciones nativas documentadas no muestran distinciones significativas de un nivel a otro o respecto a las del resto del yacimiento, por lo que nada indica que sean de un momento precedente. Para poder alcanzar a comprender en profundidad la evolución de esta zona de principio a fin, necesitaríamos de un registro estratigráfico del que carecemos por completo por lo que, teniendo en cuenta todos los datos proporcionados, parece que estamos ante una zona de una larga ocupación, del s. I al V d.C., no habiendo, por el momento, datos que permitan sostener fehacientemente una fecha previa.

\section{2. Zona este del sistema defensivo (1988-1989)}

Para la zona del sistema defensivo situado al este y excavado entre 1988 y 1989, solo hemos observado producciones nativas que muestran una gran similitud morfotecnológica respecto a las registradas en la zona noreste. También tendremos aquí ollas y cuencos de idénticas características, junto con un vaso L16. Asociamos a esta zona las mismas problemáticas que veíamos para la zona noreste. Las dos campañas realizadas aquí tampoco cuentan con un registro estratigráfico que permita discernir niveles y estratos a los que adscribir las cerámicas estudiadas. Las dataciones realizadas, de las que ignoramos su relación espacial con los materiales analizados, no están aparentemente relacionadas con ningún paquete estratigráfico, por lo que no nos permiten razonar la evolución diacrónica del lugar. No se ha documentado aquí ningún otro material que pueda ayudar a precisar la cronología de la zona estudiada, salvo el vaso tipo L16, cronológicamente situado en el s. I d. C., mientras que el resto de la cerámica no se diferencia de la de otras zonas del castro con cronologías más tardías.

\section{3. Zona sudeste del recinto central (1996)}

En la zona sudeste del recinto central (Fig. 25), excavada en 1996, las tornas se invierten, siendo la cerámica común más abundante frente a la 
cerámica nativa. En esta zona documentamos ollas, cuencos y fuentes junto con otros tipos como vasos y jarras. La cerámica nativa no presenta diferencias respeto a la de otras áreas, a excepción de las ollas de borde facetado que se identifican aquí en mayor medida.

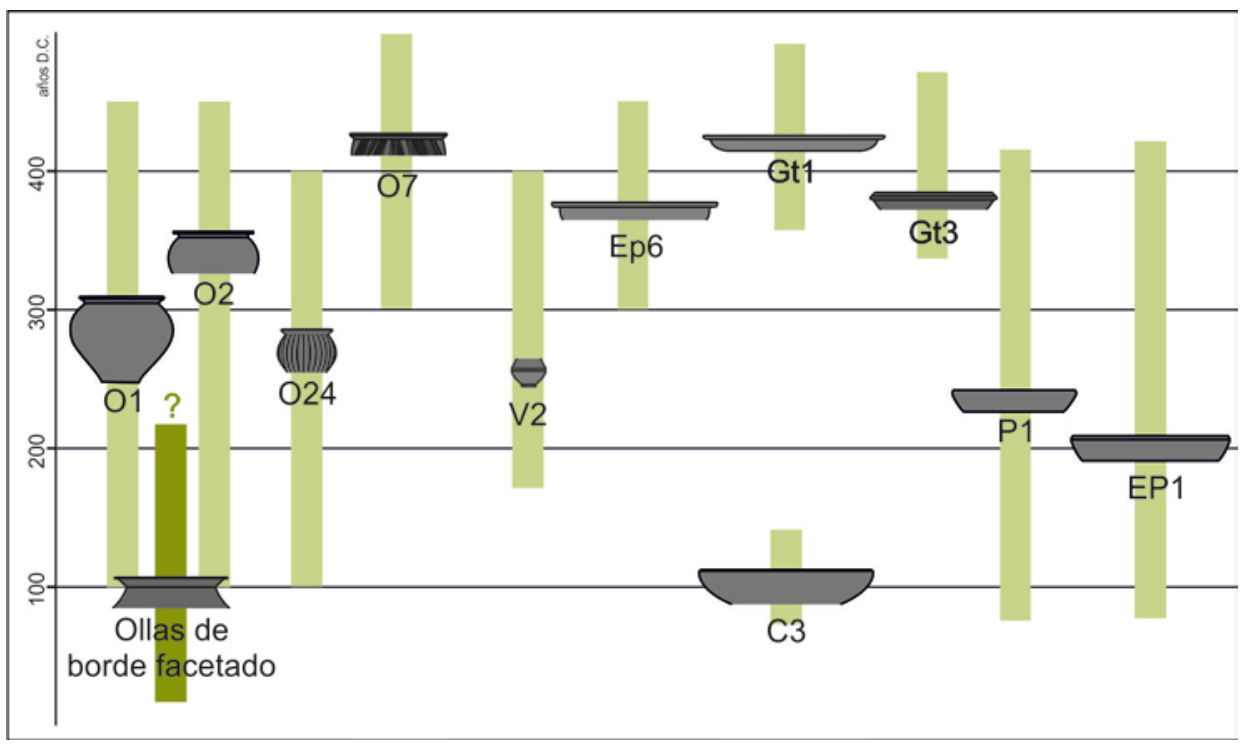

Fig. 25. Cuadro cronológico de la zona sudeste según los datos de Alcorta (2001) y Hevia et alii (2009).

Respecto a la cronología que indican estos materiales, las ollas de borde facetado han sido puestas en relación con la época altoimperial. Dentro de la cerámica común romana, encontramos tipos con una larga adscripción cronológica como las $\mathrm{O} 1$, las O2, las O24, los V2, los P1 y EP1, pero igualmente hemos documentado la presencia de cuencos C3, situados en el s. I y II d.C., y de tipos considerados tardíos, como los EP6, las O7 o las fuentes CGT, cerámicas grises tardías fechadas entre el s. IV y el s. VII d.C (Alcorta, 2001: 385).

Respecto a la estratigrafía, para esta zona se excavaron "niveis arqueolóxicos que responden a un mesmo nivel cultural” (López et alii, 1996: 48). Si comparamos los datos estratigráficos con los materiales documentados, percibimos que hay una gran homogeneidad entre las distintas unidades estratigráficas respecto a los tipos que presentan. En las unidades estratigráficas superiores encontramos las cerámicas más tardías, pero aparecen junto a 
cuencos C3, fechados en los primeros siglos del cambio de era y que se documentan también en las unidades estratigráficas inferiores. Sin embargo, es posible que estos cuencos tengan una cronología mayor que la que muestran en Lugo, algo a lo que ya se apunta en la bibliografía (Alcorta, 2001: 333).

Según la documentación administrativa y las fichas del museo, se recogieron en esta campaña cuatro fragmentos de TSH y siete de TSHT con cronologías imprecisas en las fichas que los sitúan entre el s. II y el V d.C. Asimismo, se recogieron 6 follis fechados, también según la información de las fichas, entre el s. III y el V d.C.

Teniendo en cuenta todos estos datos proponemos una cronología de ocupación con un inicio más tardío respecto a otras zonas, aunque tampoco demasiado teniendo en cuenta la pervivencia de los tipos altoimperiales, situándose la ocupación entre principios del del s. II y el IV d.C. (Fig. 25).

\section{4. Zona de expansión oeste (1996)}

En la zona de expansión oeste, también excavada en 1996, hemos observado casi de manera mayoritaria una única producción, la cerámica común romana, teniendo la cerámica nativa una presencia meramente residual. En este caso, sí que abundan las ollas respecto a los platos y las jarras, que se recogen en menor medida. De nuevo tenemos aquí unos tipos de larga duración, como las O1, O2, P1 y EP1, junto la J1, situada entre el s. III y el V, y otros de cronología bajoimperial como la O5, la EJ1 y la EJ2 (Alcorta, 2001: 204, 295 y 298).

La mayoría de los materiales seleccionados para el estudio proceden de la zona excavada en el camino, conocida como "calle III" a la que la documentación administrativa arroga un único nivel arqueológico (López González, 1996). Las dataciones realizadas por C14 en muestras de madera procedentes tanto de esta calle como del exterior de la vivienda, dan fechas opuestas (Fig. 11). El contexto de procedencia de estas muestras, un estrato bajo un muro y un nivel de derrumbe desaconseja su consideración a la hora de acotar la cronología ya que pudo haber mediado un tiempo indeterminado entre su combustión, referencia de la datación radiocarbónica, y su deposición o incorporación a estos niveles.

En esta zona también se documentó un follis fechado de forma inconcreta según las fichas de materiales existentes en el Museo de Viladonga entre el s. III y el s. V, 20 fragmentos de TSH y 33 de TSHT.

Situamos esta zona en un momento más tardío respecto a las otras, entre el s. IV y el V d.C. (Fig. 26), debido a la presencia de tipos cerámicos que inician su producción en esta fecha y que conviven en nuestras colecciones con otros 
que si bien pudieron iniciarse antes todavía existen en este momento y resultan coherentes con esta datación.

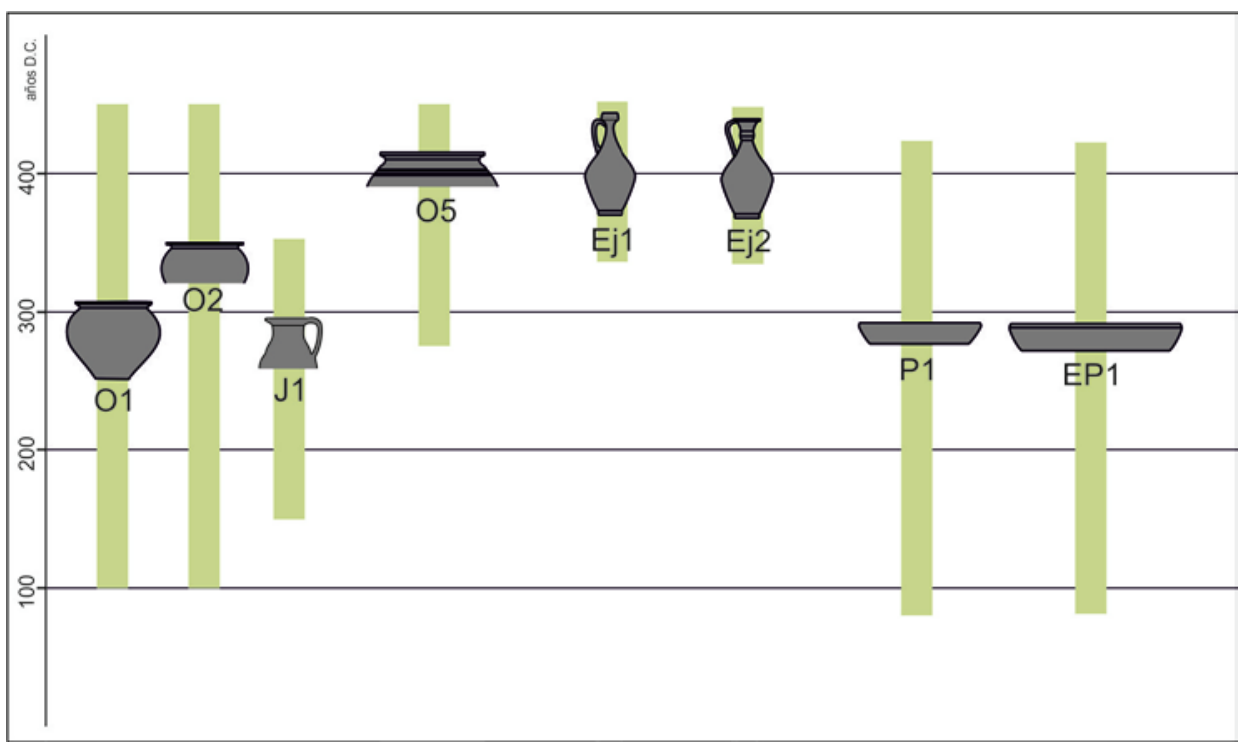

Fig. 26. Cuadro cronológico de la zona de expansión oeste según los datos de Alcorta (2001).

\section{5. Zona sudoeste del recinto central (2016)}

En la zona sudoeste del recinto, la cerámica común romana será la única producción documentada (Fig. 27). Junto a las ollas O1, O2, O24, los vasos V2 y los EP1 o P1, tipos con una amplia cronología que va del s. II y al V d.C., se documentan tipos tardíos como la cerámica gris tipo GT1, una imitacion de la Hayes 59, tipo I59, fechada en el s. IV y V d.C (Alcorta, 2001: 379) y una pieza que se asemeja a la forma Rigoir 7 de la TSGT, producción situada entre el s. IV-VI d.C. (Uscatescu et alii, 1994: 288) Estos tipos coinciden en cronología con 23 fragmentos de terra sigillata sin clasificar y con el conjunto de monedas de época de Constantino documentado en esa zona y fechado en el s. IV d.C. (López et alii, 2016: 161). Los tipos más tardíos aparecerán en todas las unidades estratigráficas de la excavación, lo que hace suponer un momento tardío en torno al s. IV-V d.C. (Fig. 27). 


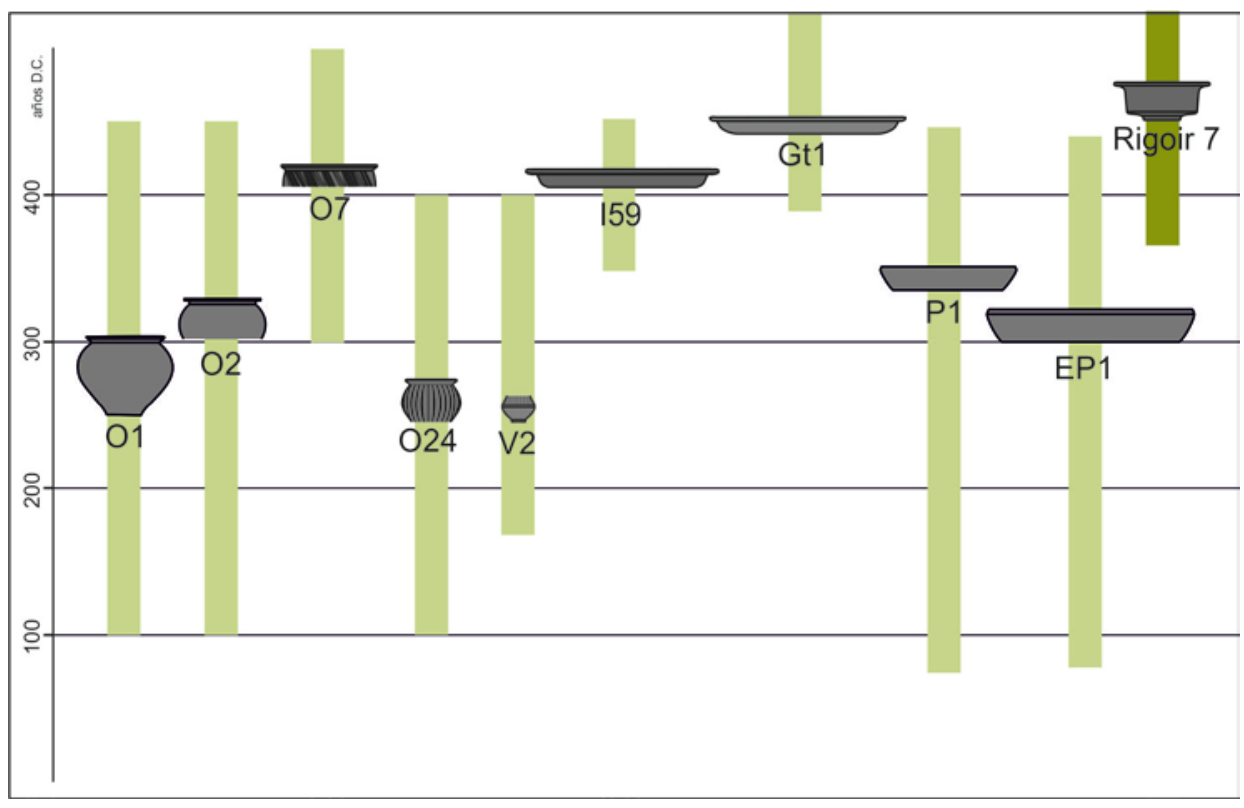

Fig. 27. Cuadro cronológico de la zona sudoeste según los datos de Alcorta (2001) y Rigoir (1968).

\section{CONCLUSIONES}

Analizando todos los materiales en su conjunto vemos que la cerámica nativa se documenta con unas características morfotecnológicas muy homogéneas en la mayoría de las zonas estudiadas. Su presencia es mayor en las zonas noreste y este del sistema defensivo, observándose en menor medida en la zona sudeste, de manera residual en la zona de expansión y estando ausente en la zona sudoeste. Esta producción tiene como característica principal una gran predominancia de las ollas sobre el resto de los grupos formales: cuencos, vasos y tazas. Los tipos considerados altoimperiales dentro de la cerámica nativa han de ser tenidos en cuenta, ya que algunos de ellos presentan formas y técnicas que posteriormente estarán presentes en tipos de la cerámica común romana con cronologías más tardías, es el caso del vaso L16, que recuerda a la posterior forma V1 (Hevia et alii, 2009: 50), o las ollas de borde facetado, muy similares a las $\mathrm{O} 1$ y O1A de la común romana (Hevia et alii, 2009: 88).

La presencia de cerámica común romana, considerada de manera conjunta, es menor que la de nativa, sin embargo, a diferencia de ésta, estará presente en todos los contextos analizados. En esta producción las ollas también tienen una 
mayor presencia frente al resto de los tipos, aunque en ningún momento de manera tan acusada como en la cerámica nativa. En menor medida aparecerán vasos, jarras, cuencos, platos y fuentes, junto con un par de morteros, un par de tiestos y algunos recipientes que imitan tipos tardíos de TSGT. Cabe destacar que observamos una menor presencia de ollas de cerámica común romana respecto a las ollas de producción nativa cuando estas dos producciones aparecen juntas, tal vez por un mayor empleo de las ollas de la segunda producción respecto a la primera para las tareas de cocina, sin embargo, los tipos característicos del servicio de mesa, como los platos, fuentes, cuencos y jarras aparecerán casi exclusivamente en la cerámica romana.

A nivel tipológico la muestra estudiada en Viladonga se puede relacionar sin grandes problemas con otros castros de su entorno más inmediato como Zoñán (Vigo García, 2007), pero también de lugares más alejados como la costa lucense (Lozano et alii, 2015) o el oeste asturiano (Hevia et alii, 2009). Respecto a la procedencia de los recipientes, por el momento no se han documentado alfares en Viladonga, lo que, unido a su semejanza formal y tecnológica con otros lugares, pudiera hacer pensar que proceden de un centro de producción común. Sin embargo, antes de intentar localizar ese centro, sería necesario comprobar que esa similitud existe también a nivel mineralógico a través de análisis arqueométricos, ya que, si la similitud no pasase de un nivel técnico y formal, el escenario sería diferente y tendríamos que hablar de múltiples centros productores de cerámicas semejantes.

Respecto a la cronología general del castro de Viladonga, la primera incógnita surge en torno a la existencia o no de una ocupación previa a la conquista romana. Los argumentos a favor de esta interpretación se basan en un pretendido nivel prerromano, cuyas estructuras y materiales, sin embargo, no resultan determinantes; en dataciones radiocarbónicas realizadas en el corte del sistema defensivo que, hasta ahora, no han podido relacionarse de manera clara con un nivel de ocupación, y en objetos tradicionalmente adscritos a momentos anteriores, unos (p.ej.: hachas pulidas y una de bronce) que pueden proceder de hallazgos fortuitos realizados por los habitantes del castro, y otros (p.ej.: torques y algún recipiente evocador de tradiciones alfareras anteriores) que pueden ser fruto de una longeva amortización debido a su gran valor intrínseco, o producidos de forma arcaizante como resultado de una idiosincrasia individual, pero todos ellos adolecen de contar con una posición estratigráfica indefinida. Ha quedado demostrado que la aparición de cerámica nativa no indica por sí sola un momento anterior a la conquista y en ausencia de un registro estratigráfico minucioso y riguroso realizar otras inferencias en este sentido resulta demasiado arriesgado.

Con los datos de los que disponemos, parece más plausible una propuesta cronológica que sitúe la zona noreste en un amplio marco cronológico, tal vez el 
s. I para sus niveles más profundos, relacionable quizás a los niveles inferiores de la parte este del sistema defensivo, mientras que los niveles superiores se inscribirían ya en un momento plenamente romano, coetáneo tal vez a la zona sudeste del recinto central y fechado entre el s. II y el V. La zona sudoeste del recinto central y la zona de expansión oeste parecen responder a una ocupación más tardía, con una cronología entre el s. IV y el V d.C.

Recientemente, en el verano de 2018, se llevó a cabo una intervención de arqueología empresarial en la zona noreste que dejó a la vista lo que se denominó en prensa escrita como "aljibe prerromano"1. Por el momento carecemos de más datos acerca de este hallazgo y de los materiales que pudieron haberse recogido, por tanto, no sabemos que lleva al equipo que lo exhumó a otorgarle esa cronología.

Esperamos que futuros estudios de materiales, así como la realización de nuevas de campañas de excavación con un correcto registro estratigráfico, ayuden a determinar las distintas fases de ocupación que se produjeron en el castro, precisando en mayor profundidad su evolución cronológica y salvando los problemas que arrastra el estudio de este yacimiento.

Por último, agradecemos al personal del Museo Arqueológico del Castro de Viladonga la ayuda prestada para la consulta de los materiales y documentación estudiados y a los dos revisores de este trabajo sus comentarios.

\section{BIBLIOGRAFÍA}

Alcorta Irastorza, Enrique (2001): Lucus Augusti II: Cerámica común romana de cocina y mesa hallada en las excavaciones de la ciudad. Lugo: Fundación Pedro Barrié de la Maza.

Arias Vilas, Felipe (1985): Castro de Viladonga. Campaña 1983, Arqueoloxía/Memorias 2. Santiago de Compostela: Xunta de Galicia.

Arias Vilas, Felipe (1987): Castro de Viladonga (Lugo). Memorias dos traballos realizados en 1984. Ejemplar depositado en el Museo de Villalonga.

Arias Vilas, Felipe (1991): "Excavación e limpeza no Castro de Viladonga (Castro de Rei, Lugo), Campaña 1988”, Arqueoloxía, Informes, 2, pp.71-75 y pp. 203-205.

1 Publicado en https://elpais.com/cultura/2018/12/09/actualidad/1544355049_758667.html, consultado el 26 de febrero de 2019. 
Arias Vilas, Felipe (1992): Campaña de excavación, limpeza e consolidación no Castro de Viladonga. Outono 1992. Informe sucinto sobre o desenvolvemento dos trabalos. Ejemplar depositado en el Museo de Villalonga.

Arias Vilas, Felipe (2000): “Os últimos traballos arqueolóxicos no castro de Viladonga (Castro de Rei, Lugo): 1988-1998”. Brigantium, 12, pp. 187-198.

Arias Vilas, Felipe (1996): “Excavación arqueolóxica e limpeza no Castro de Viladonga (Castro de Rei, Lugo), Campaña 1989”, Arqueoloxía, Informes, 3, pp. 25-28.

Arias Vilas, Felipe y Fábregas Valcarce, Ramón (2003): “Datacións radiocarbónicas do Castro de Viladonga (Lugo)”. Gallaecia, 22, pp. 193-210.

Arias Vilas, Felipe, Bastos Bernárdez, Dolores, Durán Fuentes María Consuelo y Varela Arias, Elena (2016): Museo del Castro de Viladonga. Xunta de Galicia.

Buceta Brunetti, Gonzalo y Pérez Pérez, Carolina (2011): “Da teoría á praxe: intervención na estrutura 25/26 do Castro de Viladonga”. Croa, 21, pp. 12-19.

Caamaño Gesto, José Manuel y López Rodríguez, José Ramón (1984): “Sigillatas del castro de Viladonga (Lugo)”. Gallaecia, 7-8, pp. 158-177.

Da Cruz, Mário (2007): “Vidros do castro de Viladonga (Lugo). Um caso exemplar”. Croa, 17, pp. 14-25.

Dorrego Martínez, Filomena y Rubiero Da Pena, Ana María (1998): “Consideracións sobre os temas decorativos na cerámica castrexa de Viladonga”. Croa, 8, pp. 2128.

Dorrego Martínez, Filomena y Rubiero Da Pena, Ana María (2001): “Apuntes acerca das asas na cerámica castrexa de Viladonga”, Croa, 11, pp. 25-28.

Durán Fuentes, María. Consuelo (1994): “Algúns útiles de bronce no Castro de Viladonga”. Croa, 4, pp. 14-15.

Durán Fuentes, María Consuelo (2008/2009): Catálogo de las monedas del Castro de Viladonga. Santiago de Compostela: Xunta de Galicia.

Durán Fuentes, María Consuelo, Fernández Vázquez, Pilar y Vila Martínez, Montserrat (1992): “Grafitos na cerámica do Castro de Viladonga (Lugo)”, en F. Acuña Castroviejo (coord.), Finis Terrae, Estudios en Lembranza do Prof. Dr. Alberto Balil. Santiago de Compostela: Universidade de Santiago de Compostela, pp. 315332.

Esteban Delgado, Milagros, Izquierdo Marculeta, María Teresa, Martínez Salcedo, Ana y Réchin, François (2008): "Producciones de cerámica común no torneada en el 
País Vasco peninsular y Aquitania meridional: grupos de producción, tipología y difusión”. Sautuola, XIV, pp. 183-216.

Fernández Rodríguez, Carlos (2002): “Análisis de los restos faunísticos recuperados en el Castro de Viladonga (Castro de Rei Lugo)”. Croa, 12, pp. 7-14.

Hevia González, Susana y Montes López, Rubén (2009): “Cerámica Romana Altoimperial de fabricación regional del Chao Samartín (Grandas de Salime, Asturias)”. Cuadernos de Prehistoria y Arqueología de la Universidad Autónoma de Madrid, 35, pp. 27-190.

Hevia González, Susana, Montes López, Rubén y Benéitez González, Carmen (1999):

"Cerámica común romana del Chao Samartín (Grandas de Salime - Asturias):

Vajilla de cocina y almacenamiento”. BSAA, 65, pp. 11-48.

Huguet Enguita, Esperanza (2013): "El material más usado por los antiguos. La cerámica común y de cocina”. En A. Ribera i Lacomba (coord.), Manual de Cerámica Romana. Del Mundo Helenístico al Imperio Romano. Madrid, pp. 291330.

Lage Pillado, Manuel (2004): Fíbulas galaico-romanas do Castro de Viladonga. Consellería de Cultura, Comunicación Social e Turismo. Xunta de Galicia

López González, Luis y Álvarez González, Yolanda (1996): Memoria da intervención arqueolóxica do Castro de Viladonga. Xunta de Galicia, Lugo. Ejemplar depositado en el Museo de Villalonga.

López González, Luis, Álvarez González, Yolanda, Gil Vázquez, Helena, Currás Refoxos, Brais, López Sánchez, Marcos y López, Miguel Ángel (2016): Escavación, acondicionamento e consolidación arqueoloxica no Castro de Viladonga (Castro de Rei, Lugo). Memoria 2016. Conselleria de Cultura, Educación e Ordenación Universitaria. Xunta de Galicia. Ejemplar depositado en el Museo de Villalonga.

López González, Luis, López Marcos, Miguel, López González, Pablo y Álvarez González, Yolanda (2017): “Campaña de intervención no Castro de Viladonga (2016)”. Croa, 27, pp. 16-31.

Lozano Hermida, Hugo, Caamaño Gesto, José Manuel, Ramil Rego, Eduardo y Barbazán Domínguez, Sara (2015): "El yacimiento galaico-romano de Punta do Castro (Barreiros, Lugo). Nuevas aportaciones”. Férvedes, 8, pp. 221-229.

Pérez Rozas, Álvaro (2017): “A produción téxtil na cultura castrexa: as fusaiolas do castro de Viladonga (Castro de Rei, Lugo)”. Croa, 27, pp.32-51. 
Ramil Rego, Eduardo (1997): "El castro de Vixil (Vilalba, Lugo). Estudio de materiales y nuevas perspectivas”. Férvedes, 4, pp. 81-105.

Ramil Rego, Eduardo (2010): “Análisis del objeto arqueológico: morfología descriptiva y tipología”. En A.J. López Díaz y E. Ramil Rego (eds.), Arqueoloxía: Ciencia e Restauración. Vilalba (Lugo): Museo de Prehistoria e Arqueoloxía de Vilalba. Monografías, 4, pp. 155-166.

Ramil Rego, Eduardo, Fernández Rodríguez, Carlos, Rodríguez López, Carlos, López Pérez, Catalina y Fernández Pintos, Pilar (1995): “El yacimiento de Punta do Castro (Reinante, Barreiros, Lugo) Materiales de superficie y perspectivas”. Férvedes, 2, pp. 87-115.

Ramil Rego, Pablo, Martínez Cortizas, Antonio, Arias Vilas, Felipe, Rodríguez Lovelle, Begoña y Gey Viturro, Paz (1994): "Estudio edafológico y paleobotánico realizado en el Castro de Viladonga (Castro de Rei, Lugo). Campaña 1990”. En J.F. Jordá Pardo (ed.), Actas de la II Reunión Nacional de Geoarqueología, (Madrid 1992), pp. 163-174.

Rigoir, Jaqueline (1968): “Les sigillées paléochrétiennes grises et orangées”. Gallia, XXVI (1), pp. 177-244.

Stuvier, M. y Reimer, P. J. (1993): "Extended 14C data base and revised CALIB 3.0 14C Age calibration program”, Radiocarbon 35, pp. 215-230.

Tejerizo García, Carlos; Rodríguez González, Celtia y Fernández Pereiro, Marcos (2018): “Materiais cerámicos tardíos (s. IV-VI d.C.) no castro de Viladonga”. Croa, 28, pp. 36-53.

Uscatescu Barrón, Alexandra, Fernández Ochoa, Carmen y García Díaz, Paloma (1994): "Producciones atlánticas de terra sigillata gálica tardía en la costa cantábrica de hispania”. Cuadernos de Prehistoria y Arqueología de la Universidad Autónoma de Madrid, 21, pp.183-233.

Vigo García, Abel (2007): O castro de Zoñán (Mondoñedo, Lugo) Escavacións 20022004. Mondoñedo.

Vila Martínez, Montserrat (1994): “Cerámica de paredes finas no castro de Viladonga”. Croa, 4, pp. 12-13. 